\title{
Landelijke en regionale werkloosheidsindicatoren 1991
}

Citation for published version (APA):

Wieling, M., Dekker, R., \& de Grip, A. (1991). Landelijke en regionale werkloosheidsindicatoren 1991. Researchcentrum voor Onderwijs en Arbeidsmarkt, Faculteit der Economische Wetenschappen. ROA Reports No. 8 https://doi.org/10.26481/umarep.1991008

Document status and date:

Published: 01/01/1991

DOI:

10.26481/umarep.1991008

Document Version:

Publisher's PDF, also known as Version of record

\section{Please check the document version of this publication:}

- A submitted manuscript is the version of the article upon submission and before peer-review. There can be important differences between the submitted version and the official published version of record.

People interested in the research are advised to contact the author for the final version of the publication, or visit the DOI to the publisher's website.

- The final author version and the galley proof are versions of the publication after peer review.

- The final published version features the final layout of the paper including the volume, issue and page numbers.

Link to publication

\footnotetext{
General rights rights.

- You may freely distribute the URL identifying the publication in the public portal. please follow below link for the End User Agreement:

www.umlib.nl/taverne-license

Take down policy

If you believe that this document breaches copyright please contact us at:

repository@maastrichtuniversity.nl

providing details and we will investigate your claim.
}

Copyright and moral rights for the publications made accessible in the public portal are retained by the authors and/or other copyright owners and it is a condition of accessing publications that users recognise and abide by the legal requirements associated with these

- Users may download and print one copy of any publication from the public portal for the purpose of private study or research.

- You may not further distribute the material or use it for any profit-making activity or commercial gain

If the publication is distributed under the terms of Article $25 \mathrm{fa}$ of the Dutch Copyright Act, indicated by the "Taverne" license above, 


\section{LANDELIJKE EN REGIONALE WERKLOOS- HEIDSINDICATOREN 1991}

ROA-R-1991/8

M.H. Wieling

R.J.P. Dekker

A. de Grip

\section{RESEARCHCENTRUM VOOR ONDERWIJS EN ARBEIDSMARKT}

Faculteit der Economische Wetenschappen

Rijksuniversiteit Limburg

Maastricht, september 1991 


\section{CIP-GEGEVENS VAN DE KONINKLIJKE BIBLIOTHEEK, DEN HAAG}

Wieling, M.H.

Landelijke en regionale werkloosheidsindicatoren 1991 / M.H. Wieling, R.J.P. Dekker, A. de Grip. - Maastricht : Researchcentrum voor Onderwijs en Arbeidsmarkt, Faculteit der Economische Wetenschappen, Rijksuniversiteit Limburg. - (Rapport / Researchcentrum voor Onderwijs en Arbeidsmarkt, ISSN 0922-8098; 1991/8)

Met lit. opg.

ISBN 90-5321-065-2 geb.

Trefw.: werkloosheid ; Nederland / werkloosheid ; schoolverlaters 


\section{INHOUDSOPGAVE}

2. LANDELIJKE WERKLOOSHEID VAN DE BEROEPSBEVOLKING

3. LANDELIJKE WERKLOOSHEID ONDER SCHOOLVERLATERS

4. REGIONALE WERKLOOSHEID ONDER SCHOOLVERLATERS

BIJLAGE A: LANDELIJKE WERKLOOSHEID VAN DE BEROEPSBEVOLKING

BIJLAGE B: LANDELIJKE WERKLOOSHEID ONDER SCHOOLVERLATERS 


\section{VERANTWOORDING}

Deze studie is uitgevoerd in het kader van de ontwikkeling van het informatiesysteem onderwijs-arbeidsmarkt van het Researchcentrum voor Onderwijs en Arbeidsmarkt (ROA), dat bedoeld is als informatievoorziening ten behoeve van het overheidsbeleid ten aanzien van de aansluitingsproblematiek tussen onderwijs en arbeidsmarkt in ruime zin. Een belangrijke toepassing van het informatiesysteem betreft het geautomatiseerde informatiesysteem voor studie- en beroepskeuze I-See! van het Landelijk Dienstverlenend Centrum voor Studie- en Beroepskeuzevoorlichting (LDC).

In het ROA-informatiesysteem worden werkloosheidspercentages voor een vijftigtal opleidingstypen berekend. Het gaat daarbij om landelijke werkloosheidspercentages voor de gehele beroepsbevolking en de trendmatige ontwikkeling daarvan, de landelijke werkloosheidspercentages onder schoolverlaters en de regionale werkloosheidspercentages onder schoolverlaters. Dit rapport beoogt op inzichtelijke wijze een algeheel overzicht te geven van deze landelijke en regionale werkloosheidsindicatoren, gemeten op basis van het bemiddelingsbestand zonder baan (BZB) van de arbeidsvoorzieningsorganisatie. De diverse indicatoren hebben daarbij betrekking op het midden van de maand april 1991.

Bij de berekening van de verschillende indicatoren zijn de BZB-gegevens telkens gerelateerd aan data afkomstig uit andere gegevensbestanden (zie de bijlagen $A, B$ en $C$ ). Het is niet uitgesloten dat de problemen die optreden bij het aan elkaar relateren van de uit de verschillende bronnen afkomstige data voor bepaalde opleidingstypen momenteel nog onvoldoende zijn uitgekristalliseerd. Als gevolg daarvan is het mogelijk dat sommige indicatoren voor enkele opleidingstypen een enigszins vertekend beeld geven van de werkloosheidssituatie.

Het rapport is, onder begeleiding van dr. A. de Grip, samengesteld door drs. M.H. Wieling met medewerking van drs. R.J.P. Dekker. M.E.C. Reiners assisteerde bij het verwerken van het datamateriaal. 


\section{INLEIDING}

In het ROA-informatiesysteem onderwijs-arbeidsmarkt wordt naast de prognoses over de arbeidsmarktsituatie naar opleiding en beroep ook een belangrijke plaats ingeruimd voor de monitoring van de actuele situatie op de arbeidsmarkt. Daarbij wordt voor de 49 onderscheiden opleidingstypen informatie verstrekt over de werkloosheidssituatie. Per opleidingstype worden de volgende werkloosheidsindicatoren onderscheiden:

- $\quad$ het landelijke werkloosheidspercentage;

- $\quad$ de trendmatige ontwikkeling hiervan;

- $\quad$ het landelijke werkloosheidspercentage voor schoolverlaters;

- de regionale werkloosheidspercentages voor schoolverlaters.

De 'trendmatige' ontwikkeling van het landelijke werkloosheidspercentage heeft daarbij vooralsnog betrekking op een vergelijking van de omvang van de werkloosheid in april 1991 met de werkloosheid in dezelfde maand van het voorafgaande jaar.

Voor het bepalen van de werkloosheidspercentages per opleidingstype is, zowel voor de gehele beroepsbevolking als voor de schoolverlaters, gebruik gemaakt van het zogenaamde ISVAbestand (Informatiesysteem Vraag en Aanbod) per april 1991. Dit bestand bevat gegevens die afzonderlijke arbeidsbureaus hebben geregistreerd van de bij hen ingeschreven werkzoekenden. Dit bestand is het zogenaamde bemiddelingsbestand zonder baan (BZB). Algemeen bekend is dat deze werkloosheidsinformatie gebukt gaat onder een vervuiling van het databestand. Desalniettemin is het ons inziens toch een waardevolle informatiebron voor wat betreft de onderlinge vergelijking van de werkloosheidssituatie voor de verschillende opleidingstypen.

In dit rapport staat de presentatie van de diverse indicatoren en de daaruit af te leiden informatie over de actuele arbeidsmarktsituatie voor de verschillende opleidingstypen centraal. Terwille van de overzichtelijkheid van de informatie is daarbij telkens gekozen voor een grafische presentatie, aangevuld met een summiere toelichting. Eerst worden in hoofdstuk 2 voor de verschillende opleidingstypen de landelijke werkloosheidspercentages voor de gehele beroepsbevolking en de bijbehorende ontwikkelingstrend gepresenteerd. Vervolgens wordt in hoofdstuk 3 de werkloosheid voor schoolverlaters besproken. Hoofdstuk 4 geeft een overzicht van de resultaten op regionaal niveau; het betreft hier de regionale werkloosheidspercentages voor schoolverlaters. Hoe de diverse werkloosheidsindicatoren zijn berekend wordt tenslotte besproken in de bijlagen $A, B$ en $C$. 
$-2-$

\section{LANDELIJKE WERKLOOSHEID VAN DE BEROEPSBEVOLKING}

In dit hoofdstuk wordt voor de verschillende opleidingstypen een beeld geschetst van de landelijke werkloosheidssituatie en de trendmatige ontwikkeling daarin in de periode april 1990april 1991. Daarbij wordt telkens per opleidingsniveau op basis van een grafische presentatie een vergelijkend overzicht gegeven van de werkloosheidsomvang en -ontwikkeling voor de verschillende opleidingsrichtingen op het desbetreffende niveau. De bovenste helft van de figuren heeft telkens betrekking op de landelijke werkloosheidspercentages naar opleidingstype; de onderste helft van de figuren illustreert de ontwikkeling van de werkloosheid tussen april 1990 en april 1991. 
$-3-$

Basisonderwijs, MAVO, onderbouw HAVO/VWO en lager beroepsonderwijs

Figuur 2.1. Landelijke werkloosheidspercentages van de beroepsbevolking
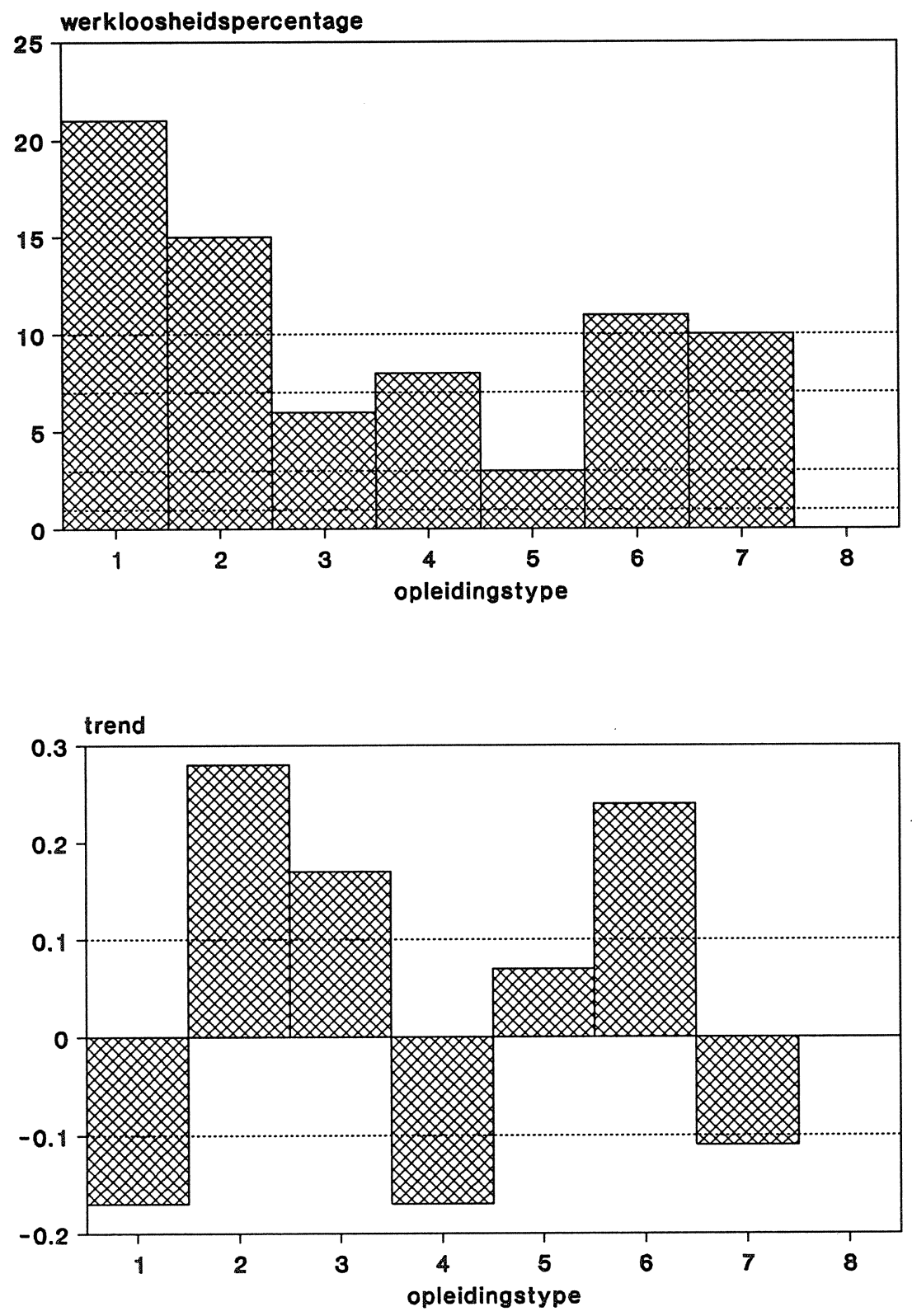

Legenda: 1 Basisonderwijs

2 MAVO en onderbouw HAVO/VWO

3 LBO Agrarisch

4 LBO Technisch
5 LBO Haven \& Vervoer

6 LBO Economisch-Administratief

7 LBO Verzorgend

8 LBO Beveiliging \& Bewaking 
$-4-$

Voor drie opleidingstypen is het werkloosheidspercentage relatief erg hoog, namelijk voor het basisonderwijs, voor het MAVO en de onderbouw van het HAVO en het VWO en voor het lager economisch en administratief onderwijs. Opvallend is daarbij, dat de opleidingstypen MAVO en onderbouw van het HAVO en het VWO en het lager economisch en administratief onderwijs naast een relatief erg hoog werkloosheidspercentage ook een stijgende trend vertonen. Verder valt op dat de werkloosheid voor mensen die alleen het basisonderwijs hebben afgerond relatief erg hoog is, maar dat de werkloosheid onder deze groep dalend is. De werkloosheid voor het lager technisch onderwijs en voor LBO Verzorgend is relatief hoog, al wordt voor beide opleidingstypen een dalende trend gevonden.

Ten aanzien van het lager agrarisch onderwijs kan worden opgemerkt dat de arbeidsmarkt min of meer in evenwicht is, met een werkloosheidspercentage op frictiewerkloosheidsniveau. De werkloosheid onder arbeidskrachten met deze opleidingsachtergrond wordt echter gekenmerkt door een stijgende trendmatige ontwikkeling.

Slechts voor één opleidingstype, LBO Haven en vervoer, is het werkloosheidspercentage relatief laag. Dit percentage is tussen 1990 en $1991 \mathrm{~min}$ of meer gelijk gebleven. Voor het opleidingstype LBO Beveiliging en bewaking worden geen werklozen geregistreerd. 
Bovenbouw HAVO/VWO en middelbaar beroepsonderwijs

Figuur 2.2. Landelijke werkloosheidspercentages van de beroepsbevolking
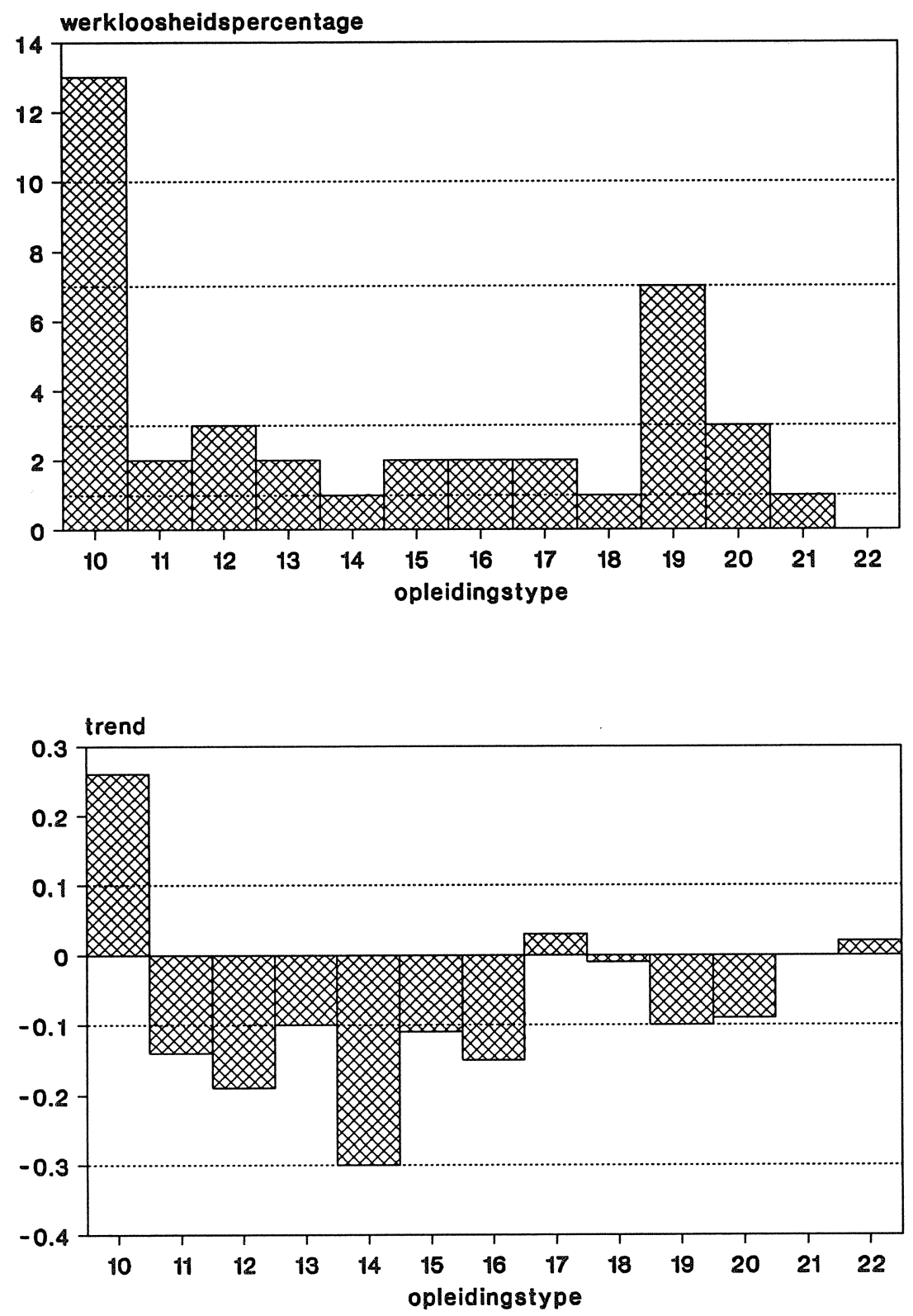

Legenda: 10 Bovenbouw HAVO/VWO

11 MBO Agrarisch

12 MBO Technisch Laboratorium

13 MBO Technisch

$14 \mathrm{MBO}$ Haven \& Vervoer

15 MBO Medisch Laboratorium

$16 \mathrm{MBO}$ Verpleging \& Ziekenverzorging
17 MBO Economisch \& Administratief 18 MBO Bestuurlijk

19 MBO Sociaal-Cultureel

20 MBO Verzorging

21 MBO Horeca \& Kappers

22 MBO Politie \& Defensie 
$-6-$

Voor mensen die een HAVO of VWO opleiding hebben afgerond, wordt een werkloosheidspercentage gemeten dat relatief zeer hoog is. Bovendien is de ontwikkeling van de werkloosheid voor mensen met deze opleidingsachtergrond ongunstig. Voor mensen met een sociaal-culturele opleiding op MBO niveau ligt de werkloosheid min of meer op frictiewerkloosheidsniveau. Bovendien is de werkloosheid voor mensen met deze opleidingsachtergrond dalend.

In het politie en defensie onderwijs op MBO niveau komen net als in 1990 bijna geen werklozen voor. Wellicht gaat het hier om mensen die vanuit hun (toekomstige) baan een opleiding volgen en derhalve na het afronden van de opleiding niet werkloos zullen worden.

Met betrekking tot de overige opleidingstypen die in figuur 2.2. worden weergegeven, wordt de werkloosheid als relatief (erg) laag getypeerd. Een erg lage werkloosheid komt voor bij de opleidingstypen MBO Haven en vervoer, MBO Bestuurlijk en MBO Horeca en kappers. Daarbij is voor de opleidingstypen MBO Economisch-administratief, MBO Bestuurlijk, MBO Verzorging en MBO Horeca en kappers de werkloosheid in de periode 1990-1991 nauwelijks veranderd. Voor de overige opleidingstypen is er sprake van een dalende werkloosheid. 
Hoger beroepsonderwijs

Figuur 2.3. Landelijke werkloosheidspercentages van de beroepsbevolking
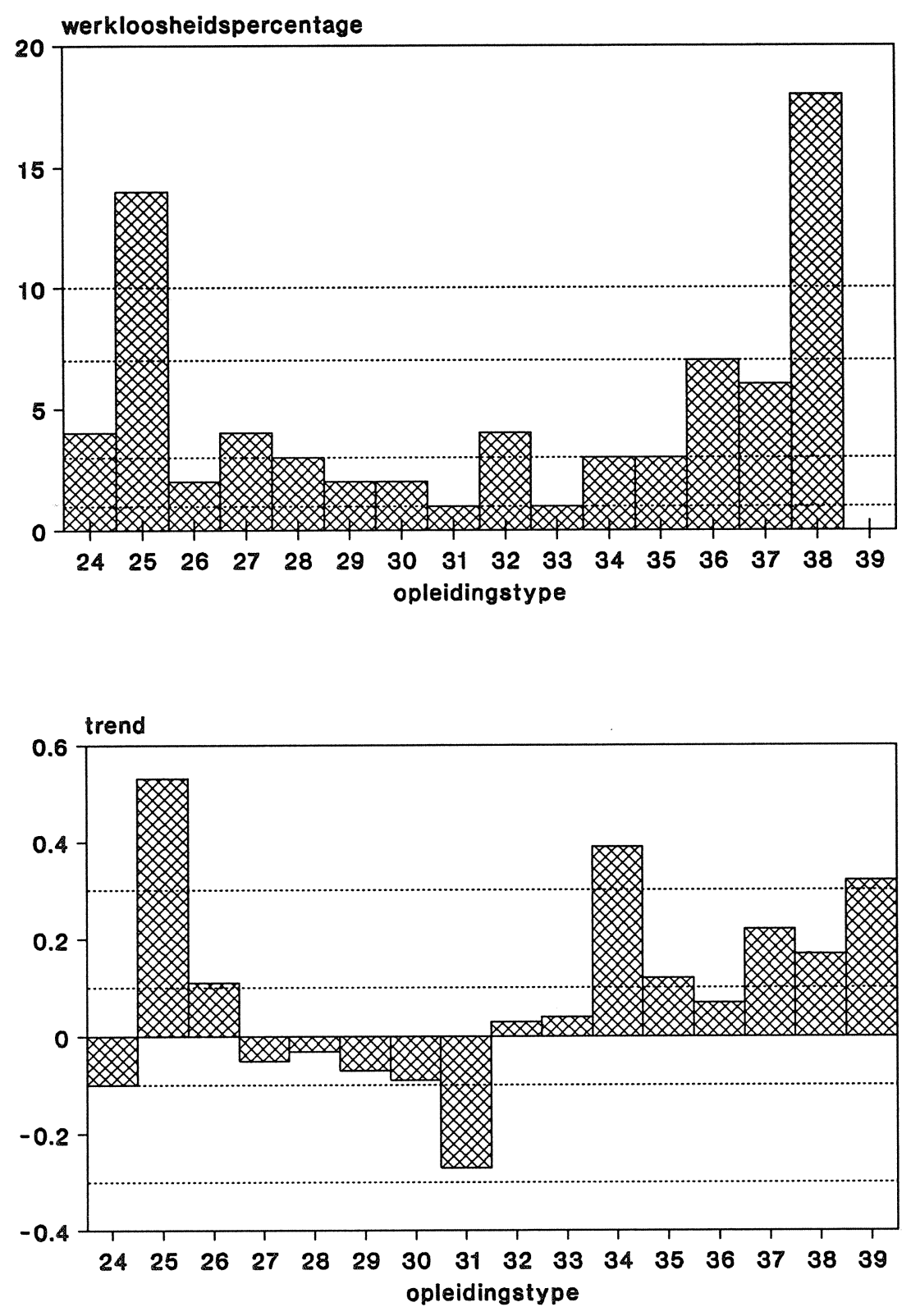

Legenda: 24 HBO Onderwijs

25 HBO Tolk \& Vertaler

26 HBO Theologisch

27 HBO Agrarisch

28 HBO Technisch Laboratorium

29 HBO Technisch

30 HBO Haven \& Vervoer

31 HBO Medisch Laboratorium
32 HBO Verpleging \& Paramedisch 33 HBO Economisch-Administratief 34 HBO Technische Bedrijfskunde 35 HBO Bestuurlijk 36 HBO Sociaal-Cultureel 37 HBO Horeca 38 HBO Kunst 39 HBO Politie \& Defensie 
$-8-$

Met name de opleidingstypen HBO Tolk en vertaler en HBO Kunst vallen op door hun relatief zeer hoge werkloosheidspercentages. Bovendien is de trendmatige ontwikkeling van de werkloosheid voor deze opleidingstypen respectievelijk sterk stijgend en stijgend.

Voor een vijftal opleidingstypen op dit opleidingsniveau ligt de werkloosheid min of meer op frictiewerkloosheidsniveau: HBO Onderwijs, HBO Agrarisch, HBO Verpleging en paramedisch, HBO Sociaal-cultureel en HBO Horeca. De ontwikkeling van de werkloosheid voor de leerkrachtenopleidingen op HBO-niveau is dalend, terwijl er voor horeca-opleidingen sprake is van een stijgende werkloosheid. Voor de andere drie opleidingstypen die zich in een situatie van arbeidsmarktevenwicht bevinden, is de werkloosheid in de periode 1990-1991 slechts weinig veranderd.

De overige opleidingstypen kennen werkloosheidspercentages die als laag kunnen worden getypeerd. Het hoger medisch laboratorium en economisch-administratief onderwijs en de politie en defensie opleidingen op HBO niveau worden zelfs door een relatief zeer laag werkloosheidspercentage gekenmerkt, waarbij de werkloosheid voor HBO Politie en defensie zelfs nihil is. Ook hier gaat het wellicht om mensen die vanuit hun (toekomstige) baan een opleiding volgen en derhalve na het afronden van de opleiding niet werkloos zullen worden. Met betrekking tot de ontwikkeling valt op dat de werkloosheid bij het medisch laboratorium onderwijs op HBO niveau dalend is. Daarentegen is er sprake van een (licht) toenemende werkloosheid bij de opleidingstypen HBO Theologisch, HBO Technische bedrijfskunde, HBO Bestuurlijk en HBO Politie en defensie. Daarbij moet worden beseft dat het hier gaat om opleidingstypen met nog steeds een (erg) lage werkloosheid. Tenslotte valt het op dat de werkloosheid voor HBO Technisch laboratorium, HBO Technisch, HBO Economischadministratief en het haven en vervoersonderwijs op HBO niveau in de periode 1990-1991 slechts weinig is veranderd. 
Wetenschappelijk onderwijs

Figuur 2.4. Landelijke werkloosheidspercentages van de beroepsbevolking
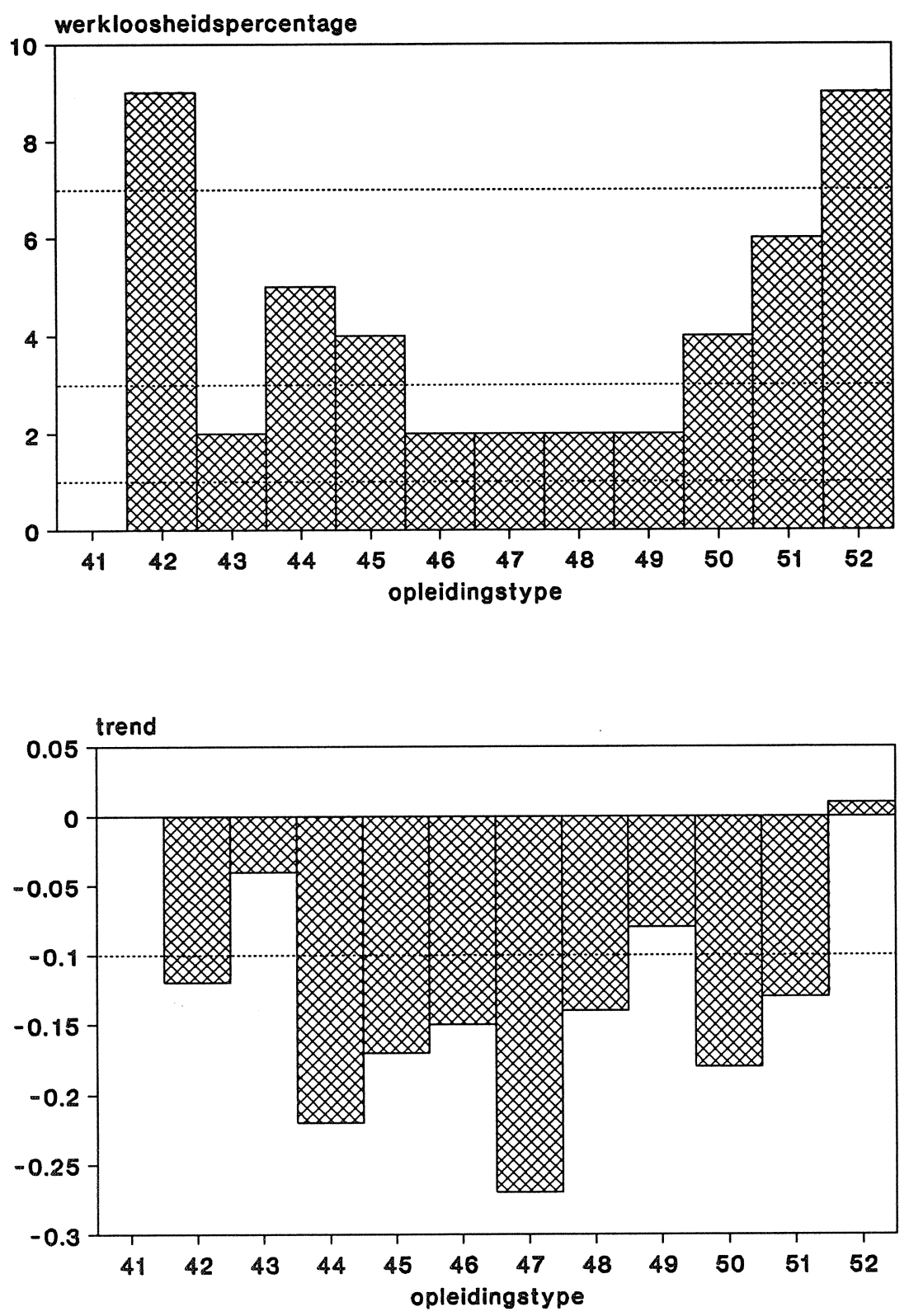

Legenda: 41 WO Onderwijs 42 WO Humaniora 43 wO Theologisch 44 WO Agrarisch 45 WO Wis- en Natuurkunde 46 WO Technisch
47 WO Dier-, Genees- \& Tandheelkunde 48 WO Farmacie

49 WO Econom(etr)ie \& Bedrijfskunde 50 WO Rechten, Bestuurskunde 51 WO Sociaal-Cultureel 52 WO Kunst 
Allereerst valt op dat het werkloosheidspercentage bij de opleidingen op WO-niveau voor geen enkel opleidingstype als erg laag wordt getypeerd'. Wel is het daarbij opmerkelijk dat voor vrijwel alle opleidingstypen, met uitzondering van WO Kunst, de werkloosheid is gedaald.

Bij WO Humaniora en WO Kunst is er sprake van een relatief hoog werkloosheidspercentage, waarbij het eerstgenoemde opleidingstype een dalende ontwikkeling laat zien, terwijl voor WO Kunst de werkloosheid ongeveer gelijk blijft.

Bij een viertal opleidingstypen is sprake van een min of meer evenwichtige arbeidsmarkt: WO Agrarisch, WO Wis- en natuurkunde, WO Rechten en bestuurskunde en WO Sociaal-cultureel. Voor deze vier opleidingstypen is de werkloosheid bovendien dalende.

Een relatief lage werkloosheid komt tenslotte voor bij de opleidingstypen WO Theologisch, WO Technisch, WO Dier-, genees- en tandheelkunde, WO Farmacie en WO Econom(etr)ie en bedrijfskunde. Daarbij is de werkloosheid voor theologie en econom(etr)ie en bedrijfskunde ongeveer constant, terwijl voor de andere drie opleidingstypen de werkloosheid is gedaald.

Op de volgende twee bladzijden staan twee overzichtstabellen die ten grondslag liggen aan de hiervoor gepresenteerde grafieken. Tabel 2.1. geeft de landelijke werkloosheidspercentages voor de beroepsbevolking per opleidingstype weer, terwijl in tabel 2.2. de bij deze werkloosheidscijfers behorende ontwikkelingstrend wordt gepresenteerd. Zowel aan de werkloosheidspercentages als aan de ontwikkelingstrend zijn kwalitatieve typeringen toegekend.

1. Voor WO-onderwijs worden werklozen niet adequaat geregistreerd. 
Tabel 2.1. Landelijke werkloosheidspercentages van de beroepsbevolking per opleidingstype

\begin{tabular}{|c|c|c|c|}
\hline \multicolumn{2}{|c|}{ opleiding } & \multirow{2}{*}{$\begin{array}{r}\text { werkloosheidspercentage } \\
21\end{array}$} & \multirow{2}{*}{$\begin{array}{l}\text { typering } \\
\text { erg hoog }\end{array}$} \\
\hline 1 & Basisonderwijs & & \\
\hline 2 & MAVO en onderbouw HAVO/VWO & 15 & erg hoog \\
\hline 3 & LBO Agrarisch & 6 & evenwicht \\
\hline 4 & LBO Technisch & 8 & hoog \\
\hline 5 & LBO Haven \& Vervoer & 3 & laag \\
\hline 6 & LBO Economisch-Administratief & 11 & erg hoog \\
\hline 7 & LBO Verzorgend & 10 & hoog \\
\hline 8 & LBO Beveiliging \& Bewaking & - & \\
\hline 10 & Bovenbouw HAVO/VWO & 13 & erg hoog \\
\hline 11 & MBO Agrarisch & 2 & laag \\
\hline 12 & MBO Technisch Laboratorium & 3 & laag \\
\hline 13 & MBO Technisch & 2 & laag \\
\hline 14 & MBO Haven \& Vervoer & 1 & erg laag \\
\hline 15 & MBO Medisch Laboratorium & 2 & laag \\
\hline 16 & MBO Verpleging \& Ziekenverzorging & 2 & laag \\
\hline 17 & MBO Economisch \& Administratief & 2 & laag \\
\hline 18 & MBO Bestuurlijk & 1 & erg laag \\
\hline 19 & MBO Sociaal-Cultureel & 7 & evenwicht \\
\hline 20 & MBO Verzorging & 3 & laag \\
\hline 21 & MBO Horeca \& Kappers & 1 & erg laag \\
\hline 22 & MBO Politie \& Defensie & 0 & erg laag \\
\hline 24 & HBO Onderwijs & 4 & evenwicht \\
\hline 25 & HBO Tolk \& Vertaler & 14 & erg hoog \\
\hline 26 & HBO Theologisch & 2 & laag \\
\hline 27 & HBO Agrarisch & 4 & evenwicht \\
\hline 28 & HBO Technisch Laboratorium & 3 & laag \\
\hline 29 & HBO Technisch & 2 & laag \\
\hline 30 & HBO Haven \& Vervoer & 2 & laag \\
\hline 31 & HBO Medisch Laboratorium & 1 & erg laag \\
\hline 32 & HBO Verpleging \& Paramedisch & 4 & evenwicht \\
\hline 33 & HBO Economisch-Administratief & 1 & erg laag \\
\hline 34 & HBO Technische Bedrijfskunde & 3 & laag \\
\hline 35 & HBO Bestuurlijk & 3 & laag \\
\hline 36 & HBO Sociaal-Cultureel & 7 & evenwicht \\
\hline 37 & HBO Horeca & 6 & evenwicht \\
\hline 38 & HBO Kunst & 18 & erg hoog \\
\hline 39 & HBO Politie \& Defensie & 0 & erg laag \\
\hline 41 & WO Onderwijs & - & \\
\hline 42 & WO Humaniora & 9 & hoog \\
\hline 43 & WO Theologisch & 2 & laag \\
\hline 44 & WO Agrarisch & 5 & evenwicht \\
\hline 45 & WO Wis-/Natuurkunde & 4 & evenwicht \\
\hline 46 & WO Technisch & 2 & laag \\
\hline 47 & WO Dier-/Genees-/Tandheelkunde & 2 & laag \\
\hline 48 & WO Farmacie & 2 & laag \\
\hline 49 & WO Econom(etr)ie \& Bedrijfskunde & 2 & laag \\
\hline 50 & WO Rechten, Bestuurskunde & 4 & evenwicht \\
\hline 51 & WO Sociaal-Cultureel & 6 & evenwicht \\
\hline 52 & WO Kunst & 9 & hoog \\
\hline
\end{tabular}


Tabel 2.2. Ontwikkelingstrend van de landelijke werkloosheidspercentages van de beroepsbevolking per opleidingstype

\begin{tabular}{|c|c|c|c|}
\hline \multicolumn{2}{|c|}{ opleiding } & \multirow{2}{*}{$\begin{array}{c}\text { trend } \\
-0.17\end{array}$} & \multirow{2}{*}{$\begin{array}{l}\text { typering } \\
\text { dalend }\end{array}$} \\
\hline 1 & Basisonderwijs & & \\
\hline 2 & MAVO en onderbouw HAVO/VWO & 0.28 & stijgend \\
\hline 3 & LBO Agrarisch & 0.17 & stijgend \\
\hline 4 & LBO Technisch & -0.17 & dalend \\
\hline 5 & LBO Haven \& Vervoer & 0.07 & constant \\
\hline 6 & LBO Economisch-Administratief & 0.24 & stijgend \\
\hline 7 & LBO Verzorgend & -0.11 & dalend \\
\hline 8 & LBO Beveiliging \& Bewaking & & \\
\hline 10 & Bovenbouw HAVO/VWO & 0.26 & stijgend \\
\hline 11 & MBO Agrarisch & -0.14 & dalend \\
\hline 12 & MBO Technisch Laboratorium & -0.19 & dalend \\
\hline 13 & MBO Technisch & -0.10 & dalend \\
\hline 14 & MBO Haven \& Vervoer & -0.30 & dalend \\
\hline 15 & MBO Medisch Laboratorium & -0.11 & dalend \\
\hline 16 & MBO Verpleging \& Ziekenverzorging & -0.15 & dalend \\
\hline 17 & MBO Economisch \& Administratief & 0.03 & constant \\
\hline 18 & MBO Bestuurlijk & -0.01 & constant \\
\hline 19 & MBO Sociaal-Cultureel & -0.10 & dalend \\
\hline 20 & MBO Verzorging & -0.09 & constant \\
\hline 21 & MBO Horeca \& Kappers & 0.00 & constant \\
\hline 22 & MBO Politie \& Defensie & 0.02 & constant \\
\hline 24 & HBO Onderwijs & -0.10 & dalend \\
\hline 25 & HBO Tolk \& Vertaler & 0.53 & sterk stijgend \\
\hline 26 & HBO Theologisch & 0.11 & stijgend \\
\hline 27 & HBO Agrarisch & -0.05 & constant \\
\hline 28 & HBO Technisch Laboratorium & -0.03 & constant \\
\hline 29 & HBO Technisch & -0.07 & constant \\
\hline 30 & HBO Haven \& Vervoer & -0.09 & constant \\
\hline 31 & HBO Medisch Laboratorium & -0.27 & dalend \\
\hline 32 & HBO Verpleging \& Paramedisch & 0.03 & constant \\
\hline 33 & HBO Economisch-Administratief & 0.04 & constant \\
\hline 34 & HBO Technische Bedrijfskunde & 0.39 & stijgend \\
\hline 35 & HBO Bestuurlijk & 0.12 & stijgend \\
\hline 36 & HBO Sociaal-Cultureel & 0.07 & constant \\
\hline 37 & HBO Horeca & 0.22 & stijgend \\
\hline 38 & HBO Kunst & 0.17 & stijgend \\
\hline 39 & HBO Politie \& Defensie & 0.32 & stijgend \\
\hline 41 & WO Onderwijs & - & \\
\hline 42 & WO Humaniora & -0.12 & dalend \\
\hline 43 & WO Theologisch & -0.04 & constant \\
\hline 44 & WO Agrarisch & -0.22 & dalend \\
\hline 45 & WO Wis-/Natuurkunde & -0.17 & dalend \\
\hline 46 & WO Technisch & -0.15 & dalend \\
\hline 47 & WO Dier-/Genees-/Tandheelkunde & -0.27 & dalend \\
\hline 48 & WO Farmacie & -0.14 & dalend \\
\hline 49 & WO Econom(etr)ie \& Bedrijfskunde & -0.08 & constant \\
\hline 50 & WO Rechten, Bestuurskunde & -0.18 & dalend \\
\hline 51 & WO Sociaal-Cultureel & -0.13 & dalend \\
\hline 52 & WO Kunst & 0.01 & constant \\
\hline
\end{tabular}




\section{LANDELIJKE WERKLOOSHEID ONDER SCHOOLVERLATERS}

In dit hoofdstuk wordt een beeld geschetst van de landelijke werkloosheidsituatie voor schoolverlaters naar opleidingstype. Net als in het voorgaande hoofdstuk wordt daarbij telkens met behulp van de grafiek per opleidingsniveau een vergelijkend overzicht gegeven van de verschillende opleidingstypen op het desbetreffende niveau.

\section{Basisonderwijs, MAVO, onderbouw HAVO/VWO en lager beroepsonderwijs}

Figuur 3.1. Landelijke werkloosheidspercentages van de schoolverlaters

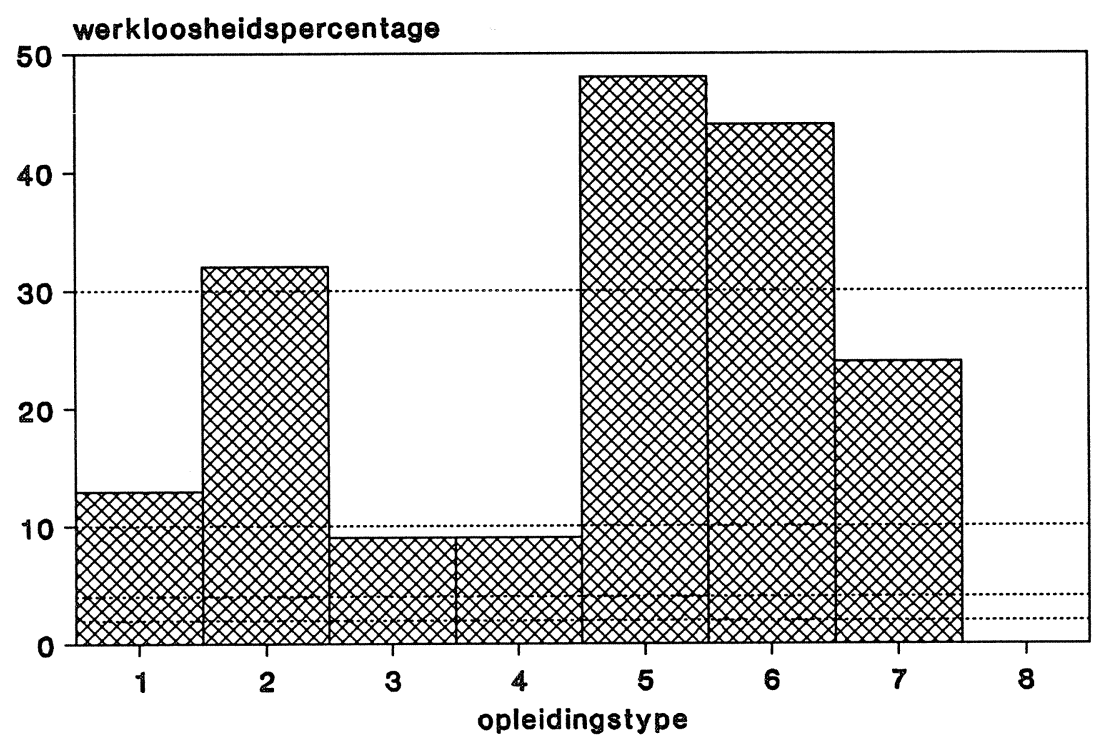

$\begin{array}{llll}\text { Legenda: } & 1 \text { Basisonderwijs } & 5 & \text { LBO Haven \& Vervoer } \\ 2 \text { MAVO en onderbouw HAVO/VWO } & 6 & \text { LBO Economisch-Administratief } \\ 3 \text { LBO Agrarisch } & 7 & \text { LBO Verzorgend } \\ 4 \text { LBO Technisch } & 8 & \text { LBO Beveiliging \& Bewaking }\end{array}$

Voor drie opleidingstypen is het werkloosheidspercentage onder schoolverlaters relatief erg hoog, namelijk voor het MAVO en de onderbouw van het HAVO en het VWO en voor het LBO Haven en vervoersonderwijs en het economisch en administratief onderwijs op LBO niveau. Verder is de werkloosheid onder schoolverlaters van het basisonderwijs en LBO Verzorgend relatief groot. Daarentegen ligt het werkloosheidspercentage onder schoolverlaters voor het lager agrarisch en technisch onderwijs op een gemiddeld niveau, in vergelijking met de werkloosheid onder schoolverlaters uit de andere opleidingstypen. 
Bovenbouw HAVO/VWO en middelbaar beroepsonderwijs

Figuur 3.2. Landelijke werkloosheidspercentages van de schoolverlaters

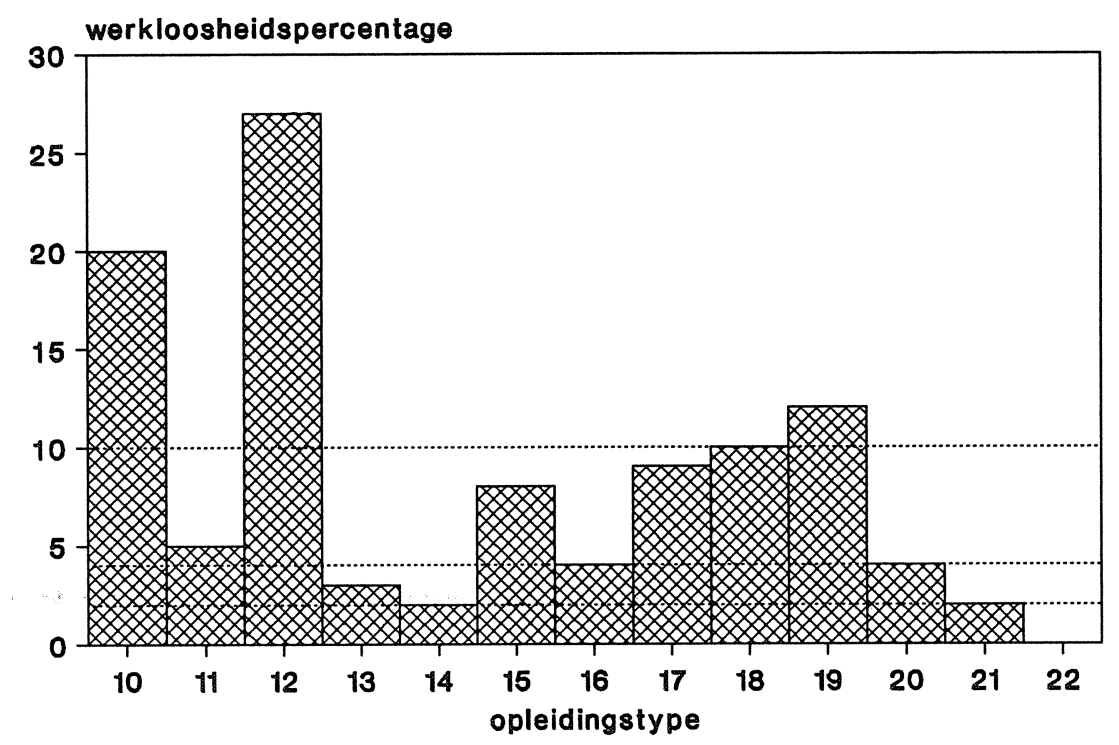

Legenda: 10 Bovenbouw HAVO/VWO

11 MBO Agrarisch

12 MBO Technisch Laboratorium

13 MBO Technisch

14 MBO Haven \& Vervoer

15 MBO Medisch Laboratorium

16 MBO Verpleging \& Ziekenverzorging
17 MBO Economisch \& Administratief

$18 \mathrm{MBO}$ Bestuurlijk

19 MBO Sociaal-Cultureel

20 MBO Verzorging

21 MBO Horeca \& Kappers

22 MBO Politie \& Defensie

Voor de schoolverlaters uit een drietal opleidingstypen op dit middelbare opleidingsniveau is de werkloosheid momenteel relatief groot. Het betreft hier de schoolverlaters die een HAVO of VWO opleiding hebben afgerond en de schoolverlaters met een sociaal-culturele opleidingsachtergrond. Het meest opvallend is nog de hoge werkloosheid onder schoolverlaters uit het middelbaar technisch laboratorium onderwijs. Voor schoolverlaters uit het haven en vervoersonderwijs en het horeca en kappersonderwijs gelden daarentegen echter werkloosheidspercentages die ten opzichte van de overige opleidingstypen op een zeer laag niveau liggen. Bij het opleidingstype MBO Politie en defensie komt zelfs in het geheel geen werkloosheid onder schoolverlaters voor. De opleidingstypen MBO Technisch, MBO Verpleging en ziekenverzorging worden gekenmerkt door een lage werkloosheid. Tenslotte liggen de werkloosheidspercentages voor schoolverlaters van de opleidingstypen MBO Agrarisch, MBO Medisch laboratorium, MBO Economisch en administratief en MBO Bestuurlijk ongeveer op het gemiddelde niveau. 


\section{Hoger beroepsonderwijs}

Figuur 3.3. Landelijke werkloosheidspercentages van de schoolverlaters

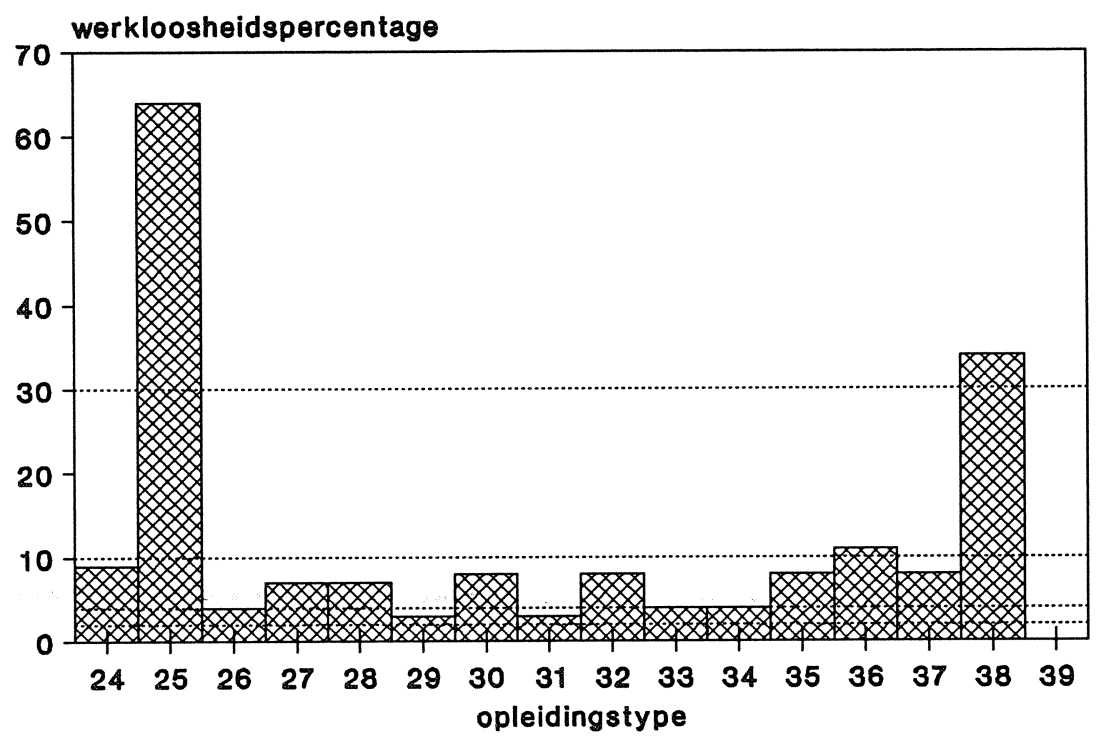

Legenda: 24 HBO Onderwijs

25 HBO Tolk \& Vertaler

26 HBO Theologisch

27 HBO Agrarisch

28 HBO Technisch Laboratorium

29 HBO Technisch

30 HBO Haven \& Vervoer

31 HBO Medisch Laboratorium
32 HBO Verpleging \& Paramedisch

33 HBO Economisch-Administratief

34 HBO Technische Bedrijfskunde

35 HBO Bestuurlijk

36 HBO Sociaal-Cultureel

37 HBO Horeca

38 HBO Kunst

39 HBO Politie \& Defensie

Met betrekking tot het hoger beroepsonderwijs valt op dat twee opleidingstypen worden gekenmerkt door een zeer hoge werkloosheid onder schoolverlaters: HBO Tolk en vertaler en HBO Kunst. Verder is het werkloosheidspercentage voor schoolverlaters met een sociaalculturele opleidingsachtergrond eveneens hoog in vergelijking met de overige opleidingstypen. Daarentegen is de werkloosheid in het theologisch, technisch, medisch laboratorium en economisch-administratief onderwijs en bij technische bedrijfskunde op HBO niveau relatief laag te noemen. Evenals voor politie en defensie opleidingen op middelbaar niveau is de werkloosheid onder schoolverlaters met deze opleidingsachtergrond op HBO niveau nihil. De overige opleidingstypen op HBO niveau vertonen een werkloosheidspercentage dat slechts weinig verschilt van het gemiddelde percentage werkloze schoolverlaters over alle opleidingstypen. 
Wetenschappelijk onderwijs

Figuur 3.4. Landelijke werkloosheidspercentages van de schoolverlaters

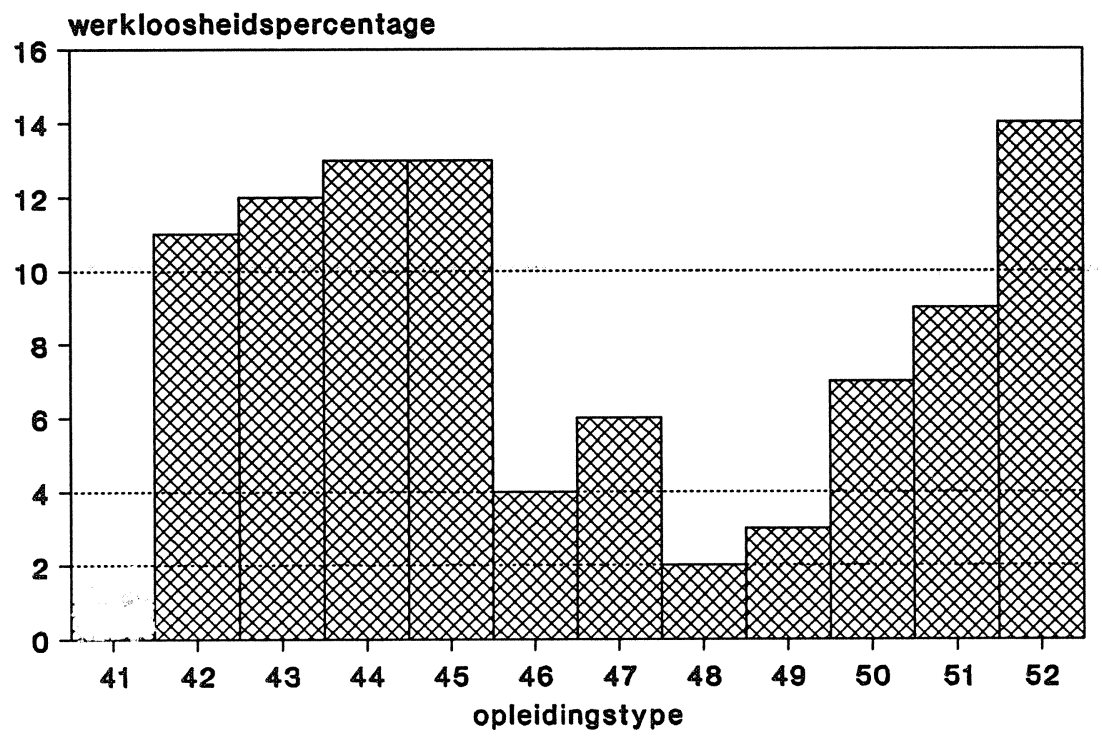

Legenda: 41 WO Onderwijs

42 WO Humaniora

43 WO Theologisch

44 WO Agrarisch

45 WO Wis- en Natuurkunde

46 WO Technisch
47 WO Dier-, Genees- \& Tandheelkunde

48 WO Farmacie

49 WO Econom(etr)ie \& Bedrijfskunde

50 WO Rechten, Bestuurskunde

51 WO Sociaal-Cultureel

52 WO Kunst

Opvallend is dat bij het wetenschappelijk onderwijs vijf opleidingstypen worden gekenmerkt door een werkloosheidspercentage onder schoolverlaters dat hoger is dan $10 \%$, hetgeen als relatief hoog kan worden getypeerd. Het gaat hier om WO-opleidingen in de humaniora, theologie, landbouwwetenschappen, wis- en natuurkunde en de kunstopleidingen. Daarentegen is de werkloosheid voor een drietal opleidingstypen (zeer) laag te noemen, namelijk voor WO Technisch, WO Econom(etr)ie en bedrijfskunde en WO Farmacie. Voor WO Dier-, genees- en tandheelkunde, WO Rechten en bestuurskunde en WO Sociaal-cultureel geldt een werkloosheidspercentage onder schoolverlaters dat overeenkomt met het gemiddelde werkloosheidspercentage van schoolverlaters over alle opleidingstypen.

Op de volgende bladzijde staat een overzicht van de in dit hoofdstuk gepresenteerde informatie. Tabel 3.1. geeft de landelijke werkloosheidspercentages onder schoolverlaters met de bijbehorende typeringen per onderscheiden opleidingstype weer. 
Tabel 3.1. Landelijke werkloosheidspercentages onder schoolverlaters per opleidingstype

\begin{tabular}{|c|c|c|c|}
\hline \multicolumn{2}{|c|}{ opleiding } & \multirow{2}{*}{$\begin{array}{r}\text { werkloosheidspercentage } \\
13\end{array}$} & \multirow{2}{*}{$\begin{array}{l}\text { typering } \\
\text { hoog }\end{array}$} \\
\hline 1 & Basisonderwijs & & \\
\hline 2 & MAVO en onderbouw HAVO/VWO & 32 & erg hoog \\
\hline 3 & LBO Agrarisch & 9 & gemiddeld \\
\hline 4 & LBO Technisch & 9 & gemiddeld \\
\hline 5 & LBO Haven \& Vervoer & 48 & erg hoog \\
\hline 6 & LBO Economisch-Administratief & 44 & erg hoog \\
\hline 7 & LBO Verzorgend & 24 & hoog \\
\hline 8 & LBO Beveiliging \& Bewaking & - & \\
\hline 10 & Bovenbouw HAVO/VWO & 20 & hoog \\
\hline 11 & MBO Agrarisch & 5 & gemiddeld \\
\hline 12 & MBO Technisch Laboratorium & 27 & hoog \\
\hline 13 & MBO Technisch & 3 & erg laag \\
\hline 14 & MBO Haven \& Vervoer & 2 & erg laag \\
\hline 15 & MBO Medisch Laboratorium & 8 & gemiddeld \\
\hline 16 & MBO Verpleging \& Ziekenverzorging & 4 & erg laag \\
\hline 17 & MBO Economisch \& Administratief & 9 & gemiddeld \\
\hline 18 & MBO Bestuurlijk & 10 & gemiddeld \\
\hline 19 & MBO Sociaal-Cultureel & 12 & hoog \\
\hline 20 & MBO Verzorging & 4 & erg laag \\
\hline 21 & MBO Horeca \& Kappers & 2 & erg laag \\
\hline 22 & MBO Politie \& Defensie & 0 & erg laag \\
\hline 24 & HBO Onderwijs & 9 & gemiddeld \\
\hline 25 & HBO Tolk \& Vertaler & 64 & erg hoog \\
\hline 26 & HBO Theologisch & 4 & erg laag \\
\hline 27 & HBO Agrarisch & 7 & gemiddeld \\
\hline 28 & HBO Technisch Laboratorium & 7 & gemiddeld \\
\hline 29 & HBO Technisch & 3 & erg laag \\
\hline 30 & HBO Haven \& Vervoer & 8 & gemiddeld \\
\hline 31 & HBO Medisch Laboratorium & 3 & erg laag \\
\hline 32 & HBO Verpleging \& Paramedisch & 8 & gemiddeld \\
\hline 33 & HBO Economisch-Administratief & 4 & erg laag \\
\hline 34 & HBO Technische Bedrijfskunde & 4 & erg laag \\
\hline 35 & HBO Bestuurlijk & 8 & gemiddeld \\
\hline 36 & HBO Sociaal-Cultureel & 11 & hoog \\
\hline 37 & HBO Horeca & 8 & gemiddeld \\
\hline 38 & HBO Kunst & 34 & erg hoog \\
\hline 39 & HBO Politie \& Defensie & 0 & erg laag \\
\hline 41 & WO Onderwijs & - & \\
\hline 42 & WO Humaniora & 11 & hoog \\
\hline 43 & WO Theologisch & 12 & hoog \\
\hline 44 & WO Agrarisch & 13 & hoog \\
\hline 45 & WO Wis-/Natuurkunde & 13 & hoog \\
\hline 46 & WO Technisch & 4 & erg laag \\
\hline 47 & WO Dier-/Genees-/Tandheelkunde & 6 & gemiddeld \\
\hline 48 & WO Farmacie & 2 & erg laag \\
\hline 49 & WO Econom(etr)ie \& Bedrijfskunde & 3 & erg laag \\
\hline 50 & WO Rechten, Bestuurskunde & 7 & gemiddeld \\
\hline 51 & WO Sociaal-Cultureel & 9 & gemiddeld \\
\hline 52 & WO Kunst & 14 & hoog \\
\hline
\end{tabular}




\section{REGIONALE WERKLOOSHEID ONDER SCHOOLVERLATERS}

In dit hoofdstuk wordt een beeld geschetst van de eventuele regionale verschillen in de ernst van de werkloosheid onder de schoolverlaters van een bepaald opleidingstype. Daarbij wordt aangesloten bij de vanuit het arbeidsvoorzieningsbeleid relevante regionale indeling in 28 RBAgebieden (zie figuur 4.1.). Eerst wordt per opleidingstype een grafisch overzicht gegeven van de relatieve verschillen in de werkloosheid onder de schoolverlaters met de desbetreffende opleidingsachtergrond. We beperken ons daarbij tot de opleidingstypen uit het AVO, LBO en MBO. Vanwege de geringe aantallen schoolverlaters en/of een niet adequate registratie van de werkloze schoolverlaters blijven de opleidingstypen Basisonderwijs (1), LBO Beveiliging en bewaking (8), MBO Horeca en Kappers (21) en MBO Politie en defensie (22) hierbij buiten beschouwing.

Voor de goede orde dient te worden opgemerkt dat het in de figuren gaat om afwijkingen van het landelijke werkloosheidspercentage voor schoolverlaters van het desbetreffende opleidingstype. Het is derhalve niet terecht een vergelijking te maken tussen de plaatjes van de verschillende opleidingstypen. Dergelijke vergelijkingen zijn wel mogelijk op basis van de daarna gepresenteerde tabellen met de waargenomen werkloosheidspercentages voor schoolverlaters naar opleidingstype. 
Figuur 4.1. De gehanteerde regio-indeling; de zogenaamde RBA-gebieden

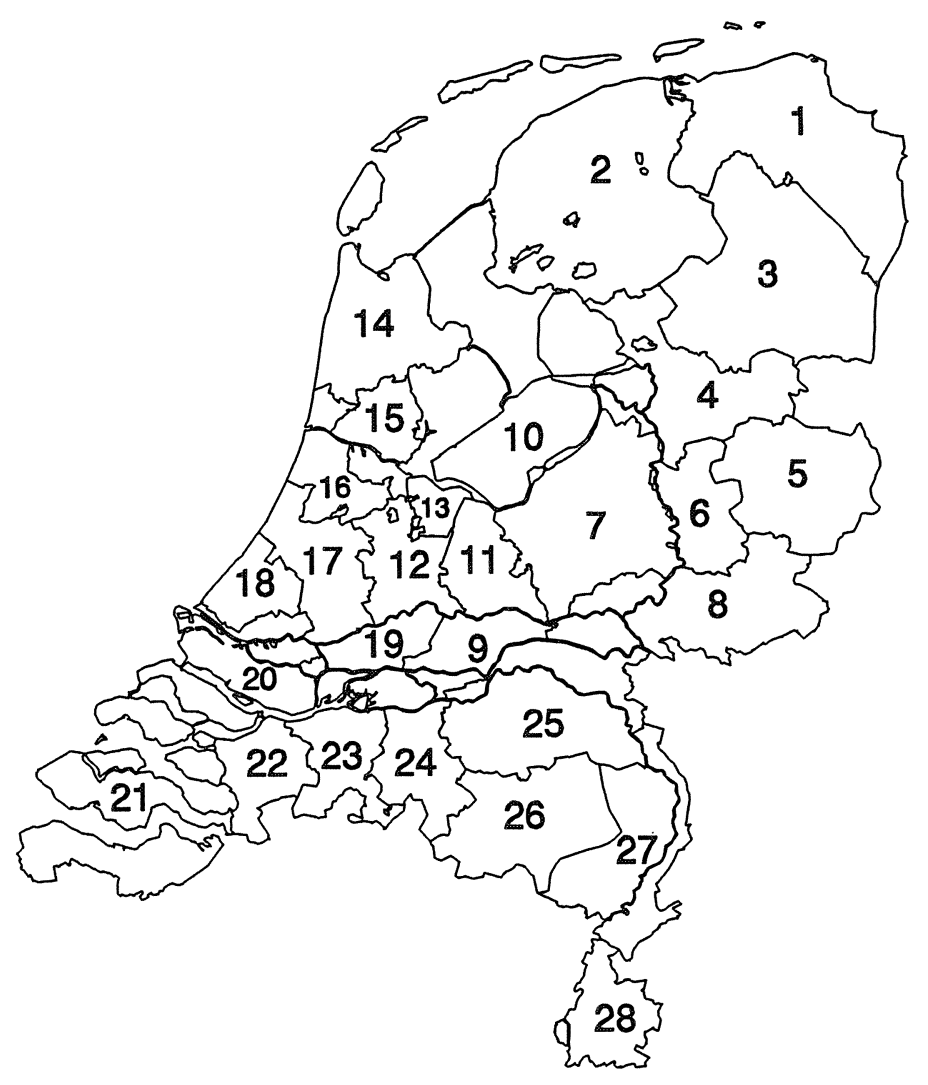

Legenda: 1 Groningen

2 Friesland

3 Drenthe

4 IJssel-Vecht

5 Twente

6 Midden-IJssel

7 Veluwe

8 Arnhem/Oost-Gelderland

9 Nijmegen/Rivierenland

10 Flevoland

11 Oost-Utrecht

12 Midden- en West-Utrecht

13 Gooi en Vechtstreek

14 Noord-Holland Noord
15 Amsterdam/Zaanstreek/Waterland

16 Kennemer-/Amstel- en Meerlanden

17 Rijnstreek

18 Den Haag/Delft

19 Drechtsteden

20 Rijnmond

21 Zeeland

22 Westelijk Noord-Brabant

23 Breda en omstreken

24 Midden-Brabant

25 Noord-Oost Brabant

26 Zuid-Oost Brabant

27 Midden- en Noord-Limburg

28 Zuid-Limburg 
Figuur 4.2. MAVO en onderbouw HAVO/VWO

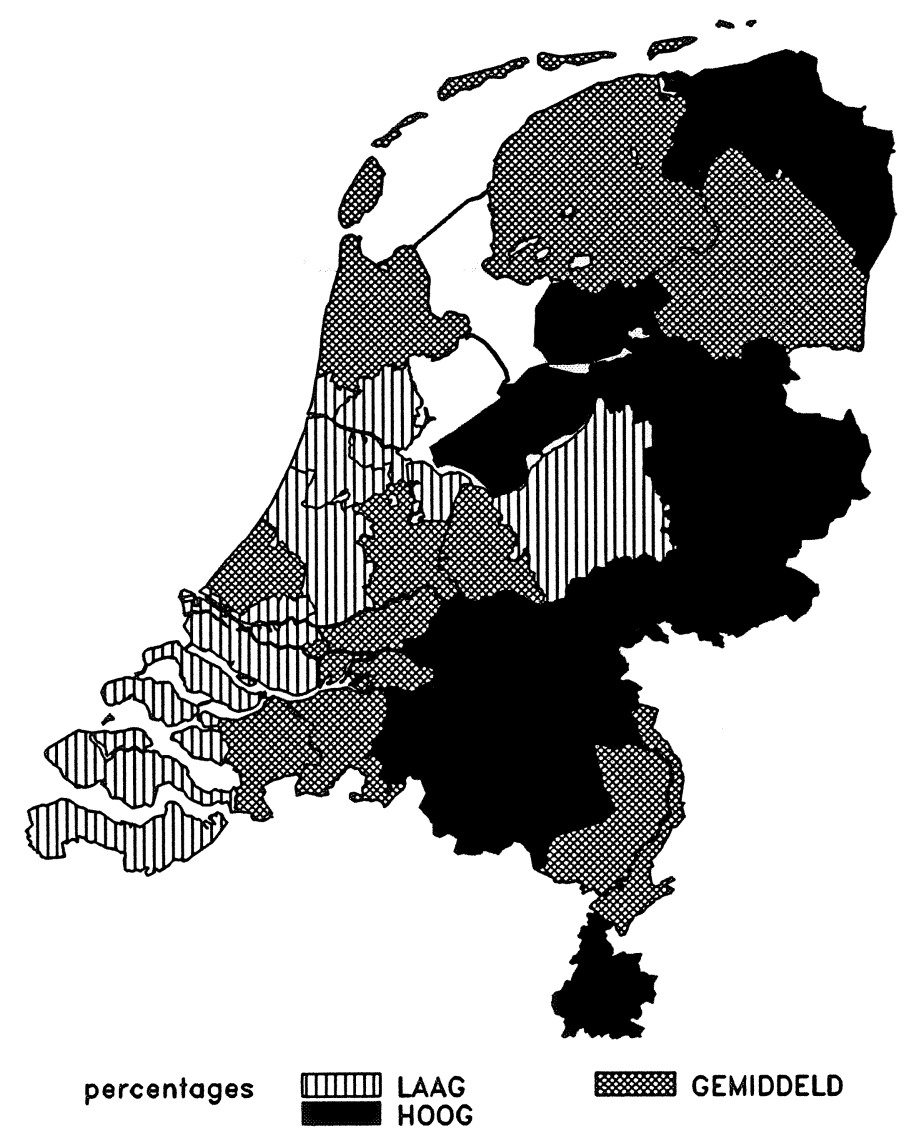

De landelijke werkloosheid onder schoolverlaters is voor het MAVO en de onderbouw van het HAVO en het VWO relatief erg hoog. Indien op basis van dit landelijke werkloosheidspercentage de verschillende RBA-gebieden met elkaar worden vergeleken valt het volgende op. In Groningen, Flevoland, Overijssel, Zuid-Limburg en het oosten van Gelderland en Brabant is de werkloosheid onder schoolverlaters met de desbetreffende opleidingsachtergrond groot. In de westelijke provincies, met uitzondering van Den Haag/Delft en Noord-Holland Noord, en de Veluwe is de werkloosheid daarentegen relatief laag ten opzichte van de landelijke werkloosheid voor dit opleidingstype. Voor Friesland, Drenthe, Noord-Holland Noord, Den Haag/Delft, Middenen Noord-Limburg en het midden van het land zijn de werkloosheidspercentages ongeveer gelijk aan het landelijke werkloosheidspercentage voor schoolverlaters van dit opleidingstype. 
Figuur 4.3. LBO Agrarisch

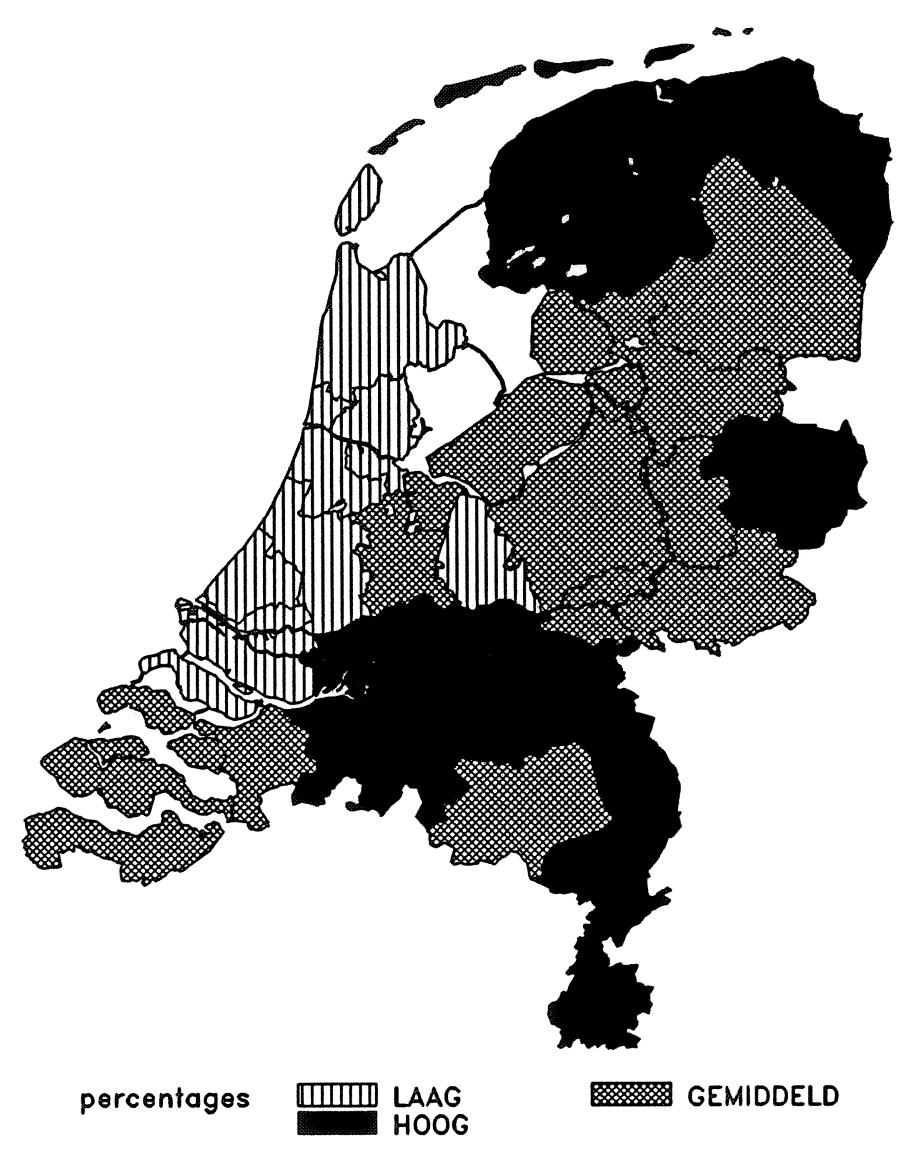

Voor schoolverlaters die een opleiding in het lager agrarisch onderwijs hebben afgerond, is de landelijke werkloosheid ongeveer gelijk aan het gemiddelde van de werkloosheidspercentages van alle onderscheiden opleidingstypen. Indien op basis van dit landelijke werkloosheidspercentage de verschillende RBA-gebieden met elkaar worden vergeleken valt direct op dat vooral in het westen van het land, exclusief Zeeland en Westelijk Noord-Brabant, en inclusief OostUtrecht de werkloosheid onder schoolverlaters met deze opleidingsachtergrond relatief laag is ten opzichte van het landelijke gemiddelde voor dit opleidingstype. In Groningen, Friesland, Twente, Brabant (met uitzondering van Oost-Brabant) en Limburg is er daarentegen sprake van een relatief hoge werkloosheid. In Drenthe, Overijssel (exclusief Twente), Gelderland, Zeeland, Midden- en West-Utrecht, Gooi en Vechtstreek, Westelijk Noord-Brabant en Zuid-Oost Brabant is de werkloosheid ongeveer gelijk aan het landelijke werkloosheidspercentage voor schoolverlaters van dit opleidingstype. 
Figuur 4.4. LBO Technisch

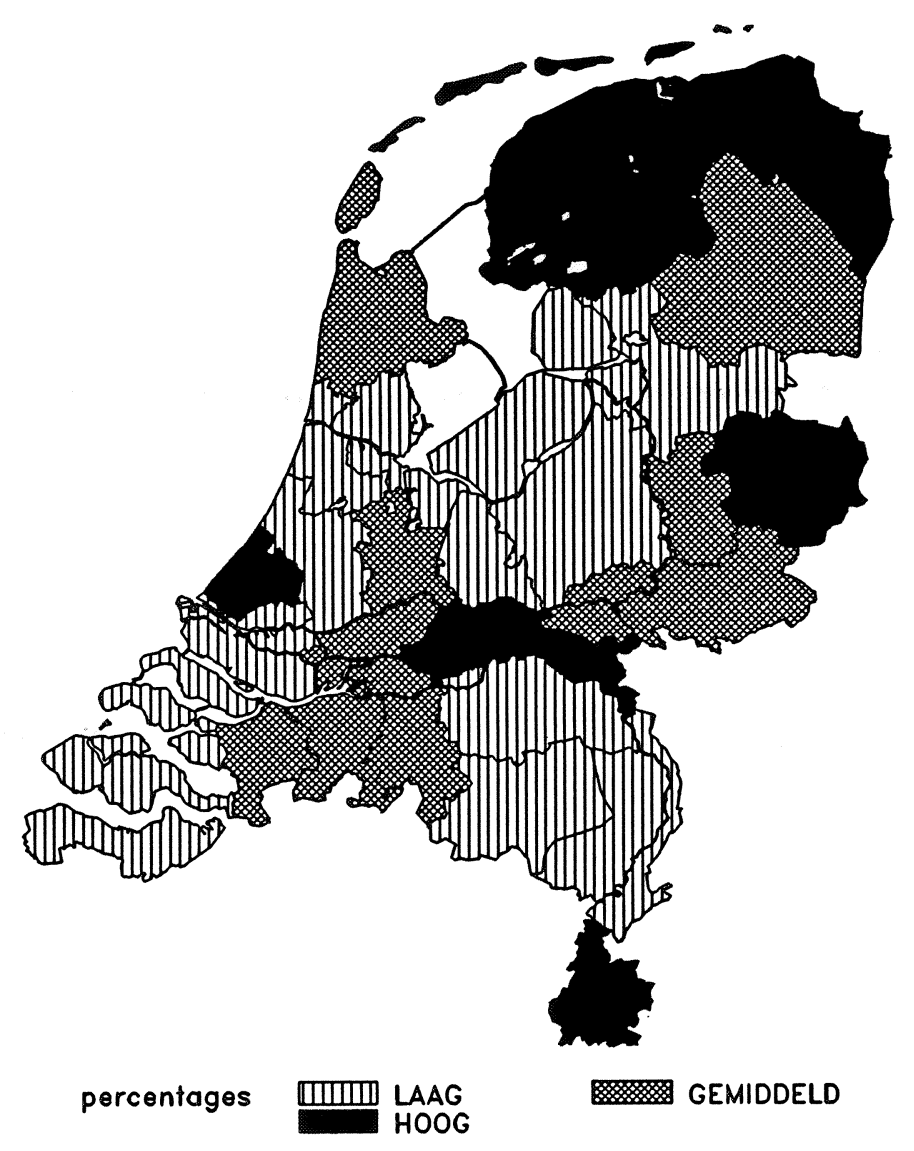

Schoolverlaters die een opleiding in het lager technisch onderwijs hebben gevolgd zien zich geconfronteerd met een landelijk werkloosheidspercentage dat ongeveer gelijk is an het gemiddelde van de werkloosheidspercentages over alle opleidingstypen. Bij het vergelijken van de werkloosheid in de verschillende RBA-gebieden met de landelijke werkloosheid onder schoolverlaters van dit opleidingstype valt het volgende op. Met name in Groningen, Friesland, Twente, Nijmegen/Rivierenland, Den Haag/Delft en Zuid-Limburg is de werkloosheid onder schoolverlaters met de desbetreffende opleidingsachtergrond relatief hoog ten opzichte van de landelijke werkloosheid onder schoolverlaters voor dit opleidingstype. Daarnaast is in de RBAgebieden Drenthe, Noord-Holland Noord, Midden-IJssel, Arnhem/Oost-Gelderland, Midden- en West-Utrecht, de Drechtsteden en het oostelijke deel van Brabant sprake van een werkloosheid onder schoolverlaters die overeen komt met het landelijk werkloosheidspercentage onder schoolverlaters met deze opleidingsachtergrond. 
Figuur 4.5. LBO Haven en Vervoer

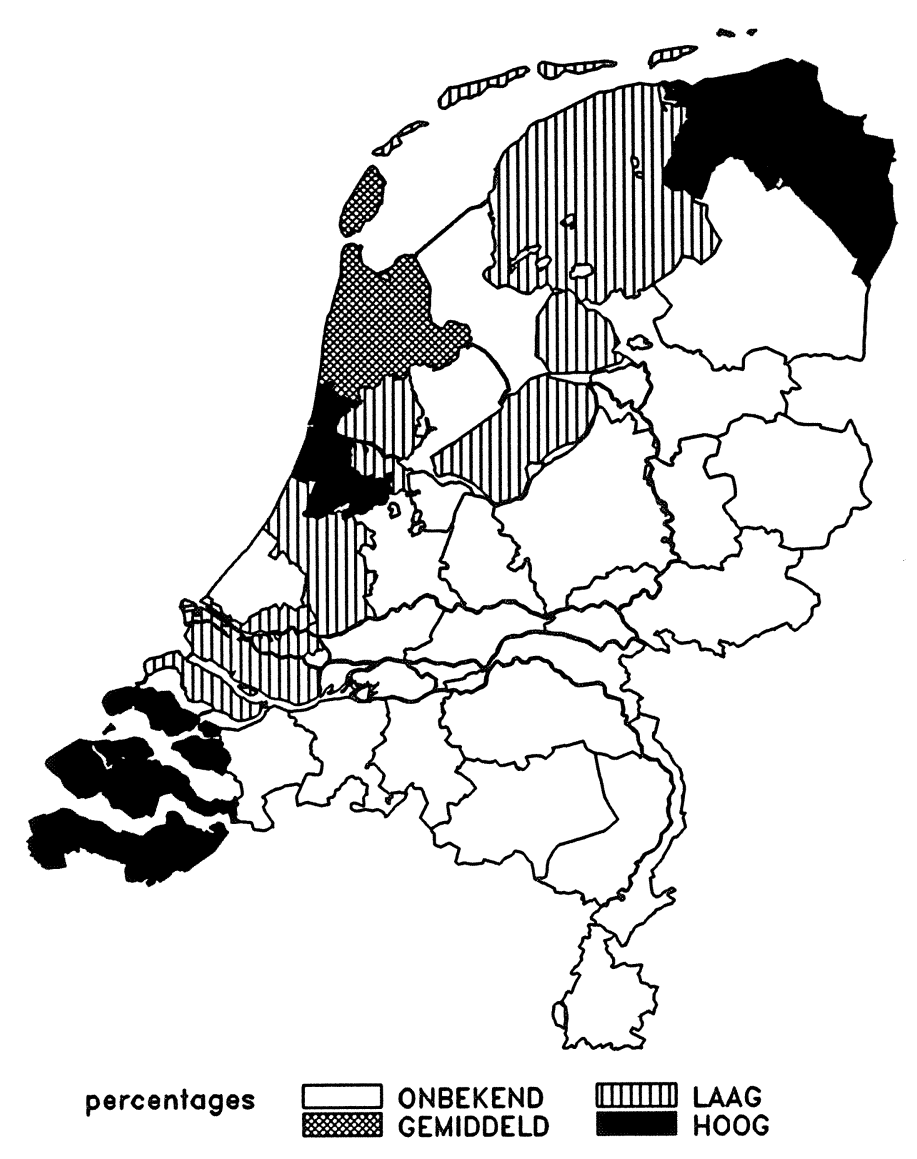

De landelijke werkloosheid onder schoolverlaters is relatief erg hoog voor het haven- en vervoersonderwijs op lager niveau. Ook voor deze opleiding worden de regionale werkloosheidspercentages vergeleken met de landelijke werkloosheid onder schoolverlaters met dezelfde opleidingsachtergrond. Daarbij moet echter worden opgemerkt dat alleen in de noordelijke en westelijke RBA-gebieden, met uitzondering van Den Haag/Delft, de uitstroom uit het onderwijs op meer dan 10 schoolverlaters wordt geschat. Het valt op dat Groningen, de Kennemer-, Amstel- en Meerlanden en Zeeland worden gekenmerkt door een relatief hoog werkloosheidspercentage. Daarnaast is de werkloosheid voor Noord-Holland Noord ongeveer gelijke aan het landelijke werkloosheidspercentage voor schoolverlaters in dit opleidingstype. In de overige RBA-regio's waarvoor een uitstroom van meer dan 10 personen wordt berekend, is sprake van een relatief lage werkloosheid ten opzichte van het landelijke werkloosheidspercentage voor dit opleidingstype. 
Figuur 4.6. LBO Economisch-Administratief

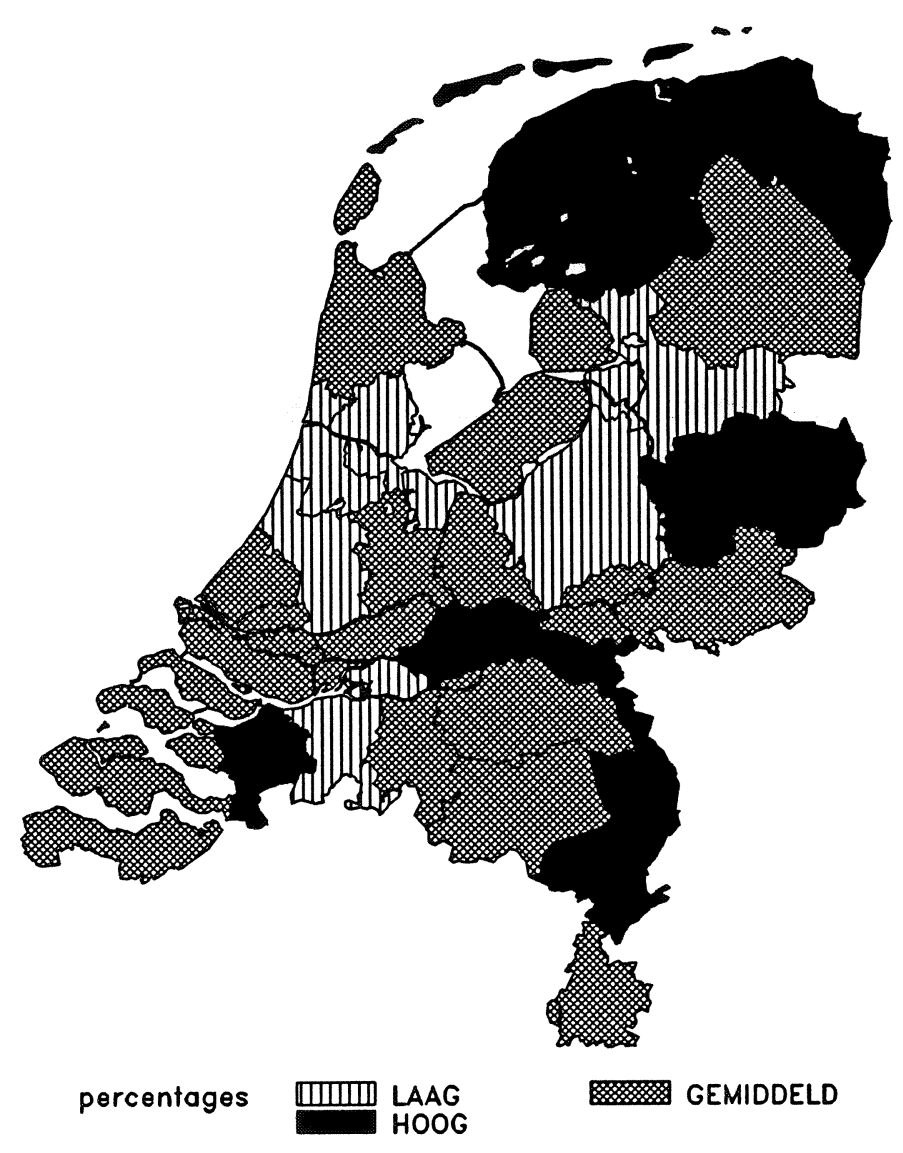

Met betrekking tot de landelijke werkloosheid onder schoolverlaters die het lager economisch en administratief onderwijs hebben afgerond is er sprake van een relatief erg hoge werkloosheid. Bij het vergelijken van de werkloosheidspercentages in de verschillende RBA-gebieden voor dit opleidingstype valt het volgende op. Vooral in Groningen, Friesland, Twente, Midden-IJssel, Nijmegen/Rivierenland, Westelijk Noord-Brabant en Midden- en Noord-Limburg is de werkloosheid onder schoolverlaters relatief hoog ten opzichte van het landelijke percentage. Voor de RBA-regio's IJssel-Vecht, Veluwe, Amsterdam/Zaanstreek/Waterland, de Kennemer-, Amstel- en Meerlanden, Rijnstreek en Breda en omstreken gelden daarentegen relatief lage werkloosheidspercentages. Schoolverlaters met deze opleidingsachtergrond in Drenthe, Flevoland, Noord-Holland Noord, Oost-, Midden- en West-Utrecht, Den Haag/Delft, Drechtsteden, Rijnmond, Zeeland, het westen van Brabant en Zuid-Limburg worden gekenmerkt door werkloosheidspercentages die overeenkomen met het landelijke werkloosheidspercentage onder schoolverlaters met deze opleidingsachtergrond. 
Figuur 4.7. LBO Verzorgend

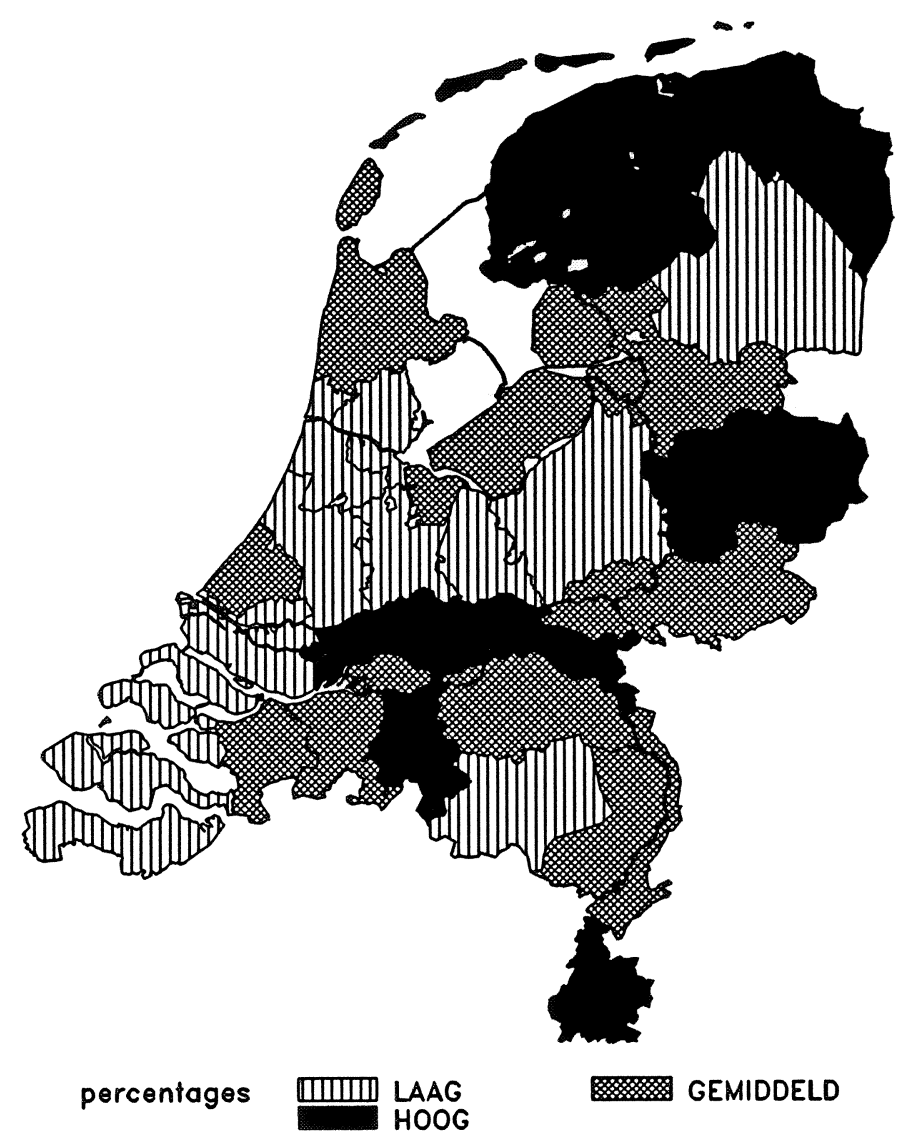

Voor schoolverlaters die een opleiding in het lager verzorgend onderwijs hebben afgerond, is het landelijke werkloosheidspercentage relatief hoog. Wanneer we de werkloosheidspercentages voor de verschillende RBA-gebieden met elkaar vergelijken, valt het op dat vooral in Drenthe, Veluwe, Oost, Midden- en West Utrecht, Amsterdam/Zaanstreek/Waterland, Kennemer-, Amstel- en Meerlanden, Rijnstreek, Rijnmond, Zeeland en Zuid-Oost Brabant de werkloosheid laag is ten opzichte van het landelijke werkloosheidspercentage voor schoolverlaters met deze opleidingsachtergrond. In Groningen, Friesland, Twente, Midden-IJssel, Nijmegen/Rivierenland, Drechtsteden, Midden Brabant en Zuid-Limburg is de werkloosheid daarentegen relatief hoog. In de overige RBA-gebieden komt de werkloosheid overeen met de landelijke werkloosheid onder schoolverlaters van dit opleidingstype. 
Figuur 4.8. Bovenbouw HAVO/VWO

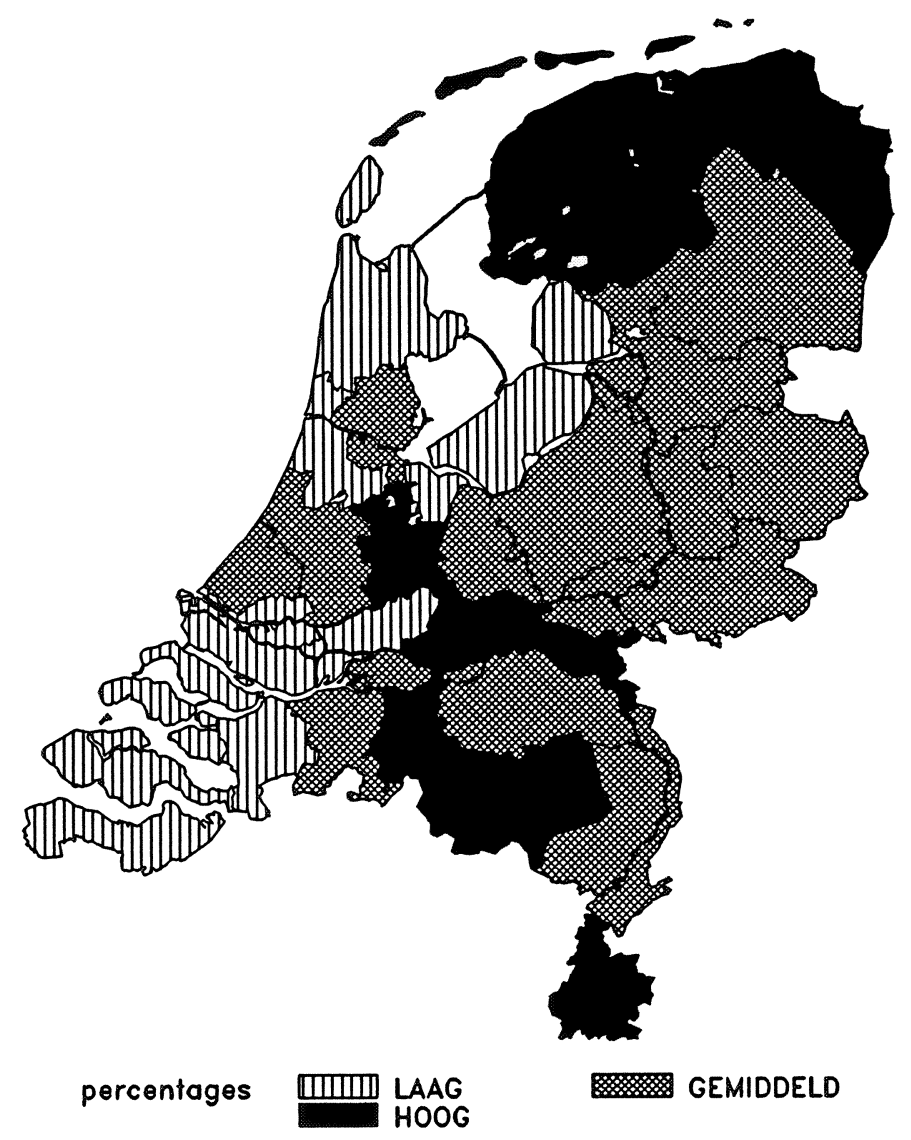

Met betrekking tot de bovenbouw van het HAVO en het VWO is de landelijke werkloosheid onder schoolverlaters relatief hoog ten opzichte van de overige opleidingstypen. Bij het vergelijken van de werkloosheid in de verschillende RBA-gebieden op basis van dit landelijke werkloosheidspercentage, valt op dat in Groningen, Friesland, Midden- en West-Utrecht, Nijmegen/Rivierenland, Midden- en Zuid-Oost Brabant en Zuid-Limburg de werkloosheid onder schoolverlaters relatief hoog is voor schoolverlaters met deze opleidingsachtergrond. Daarentegen is de werkloosheid in Flevoland, Noord-Holland Noord, Kennemer-, Amstel- en Meerlanden, Gooi en Vechtstreek, Drechtsteden, Rijnmond, Zeeland en Westelijk Noord-Brabant relatief laag. De werkloosheid in Drenthe, Overijssel, Gelderland, Oost-Utrecht, Amsterdam/Zaanstreek/Waterland, de Rijnstreek, Den Haag/Delft, Breda en omstreken, NoordOost Brabant en Midden- en Noord-Limburg komt ongeveer overeen met de landelijke werkloosheid onder schoolverlaters met deze opleidingen. 
Figuur 4.9. MBO Agrarisch

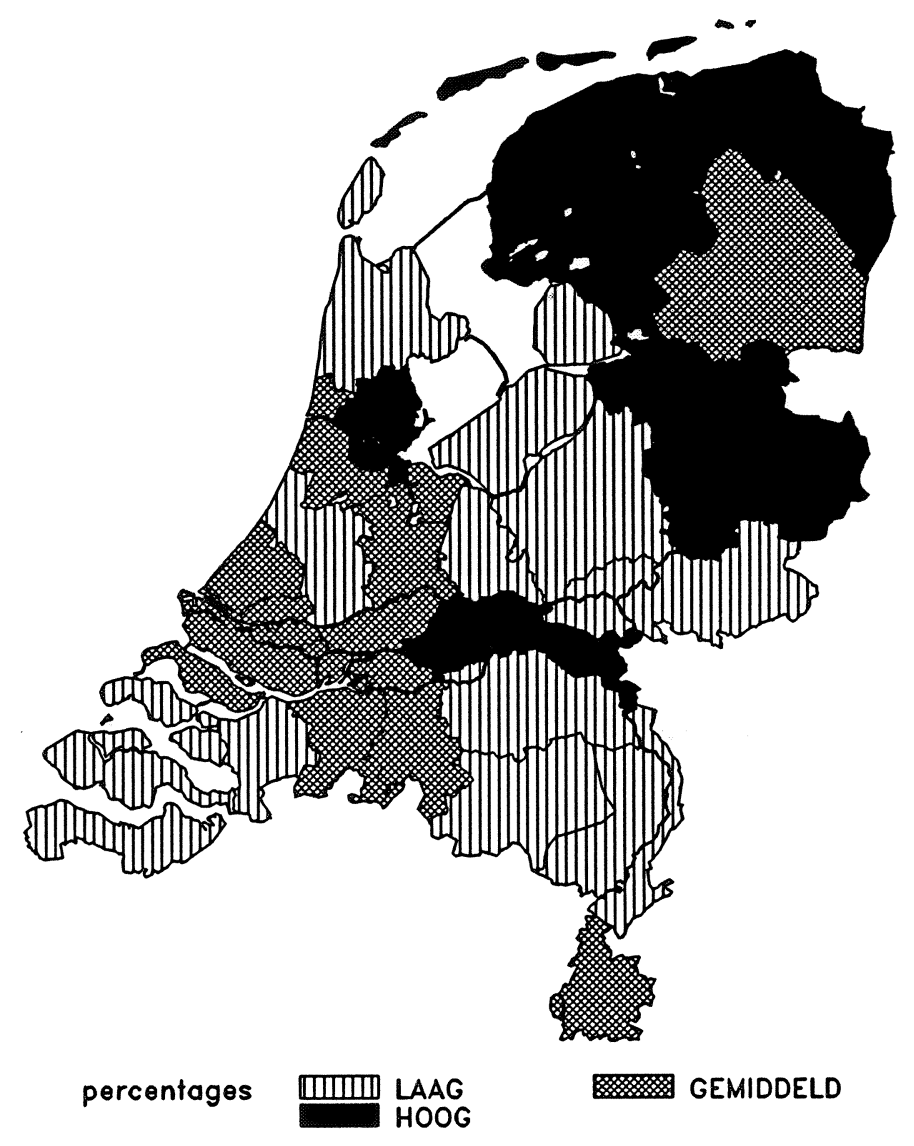

Voor schoolverlaters die een opleiding in het middelbaar agrarisch onderwijs hebben afgerond, is de landelijke werkloosheid ongeveer gelijk aan het gemiddelde van de werkloosheidspercentages voor schoolverlaters van alle onderscheiden opleidingstypen. Bij het vergelijken van de werkloosheidspercentages in de verschillende RBA-gebieden valt het volgende op. Vooral in Groningen, Friesland, Midden-IJssel, Twente, Midden-IJssel, Amsterdam/Zaanstreek/Waterland en Nijmegen/Rivierenland is de werkloosheid hoger dan het landelijke werkloosheidspercentage onder schoolverlaters met deze opleidingsachtergrond. Verder is de werkloosheid in Drenthe, Kennemer-, Amstel- en Meerlanden, Gooi en Vechtstreek, Midden- en West Utrecht, Den Haag/Delft, de Drechtsteden, Rijnmond, Breda en omstreken, Midden-Brabant en Zuid-Limburg ongeveer gelijk aan het landelijke percentage. Tenslotte geldt een relatief lage werkloosheid onder schoolverlaters voor Flevoland, Veluwe, Arnhem/Oost-Gelderland, Oost-Utrecht, NoordHolland Noord, Rijnstreek, Zeeland, Westelijk Noord-Brabant, Noord-Oost Brabant, Zuid-Oost Brabant en Midden- en Noord-Limburg. 
Figuur 4.10. MBO Technisch Laboratorium

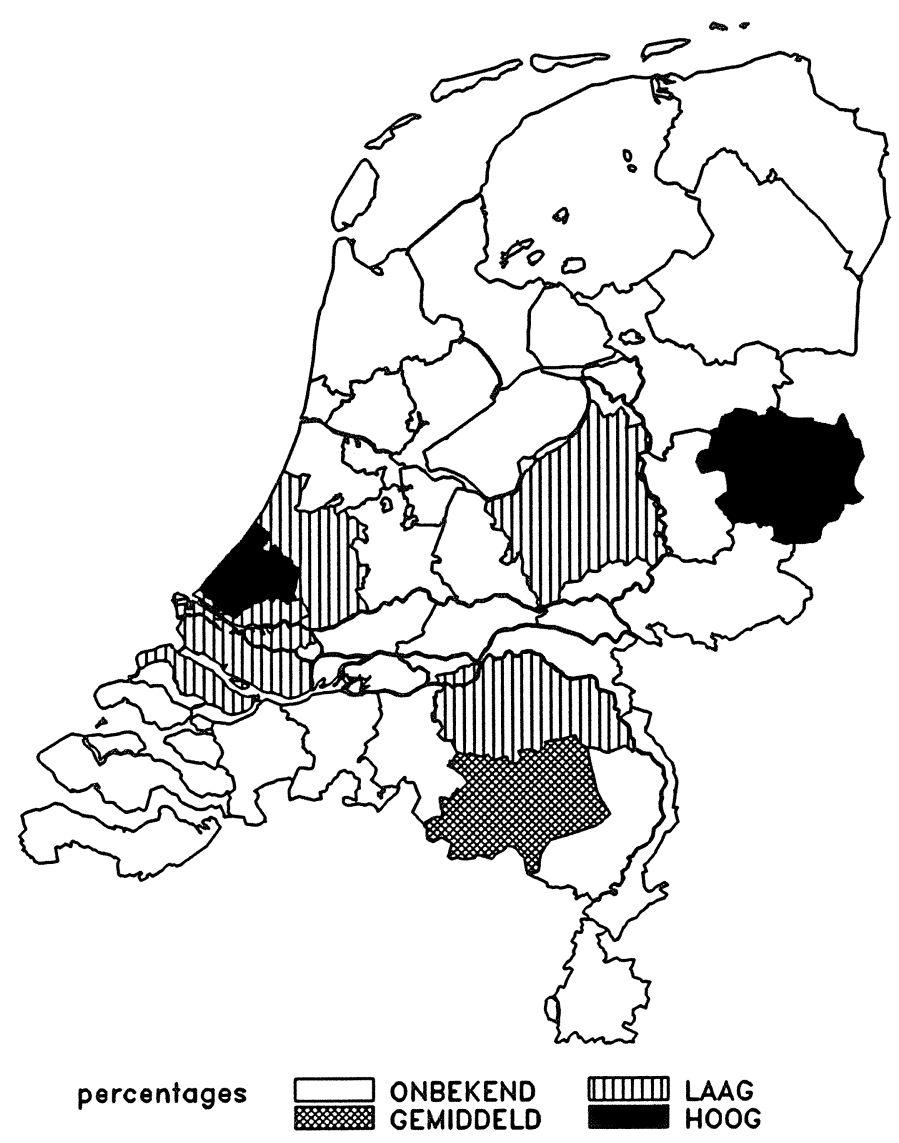

Het middelbaar technisch laboratorium onderwijs wordt gekenmerkt door een relatief hoge landelijke werkloosheid onder schoolverlaters. Voordat de verschillende RBA-gebieden met elkaar worden vergeleken, moet worden opgemerkt dat voor slechts zeven RBA-gebieden een uitstroom uit het onderwijs naar de arbeidsmarkt van meer dan 10 personen wordt geschat. Een vergelijking van de werkloosheidspercentages in deze RBA-gebieden met het landelijke werkloosheidspercentage voor schoolverlaters van dit opleidingstype laat zien dat Twente en Den Haag/Delft worden gekenmerkt door een relatief hoog werkloosheidspercentage. In ZuidOost Brabant is het werkloosheidspercentage onder schoolverlaters ongeveer gelijk aan het landelijke percentage onder schoolverlaters met deze opleidingsachtergrond. Tenslotte is de werkloosheid voor de overige vier RBA-gebieden, Veluwe, Rijnstreek, Rijnmond en Noord-Oost Brabant, relatief laag te noemen. 
Figuur 4.11. MBO Technisch

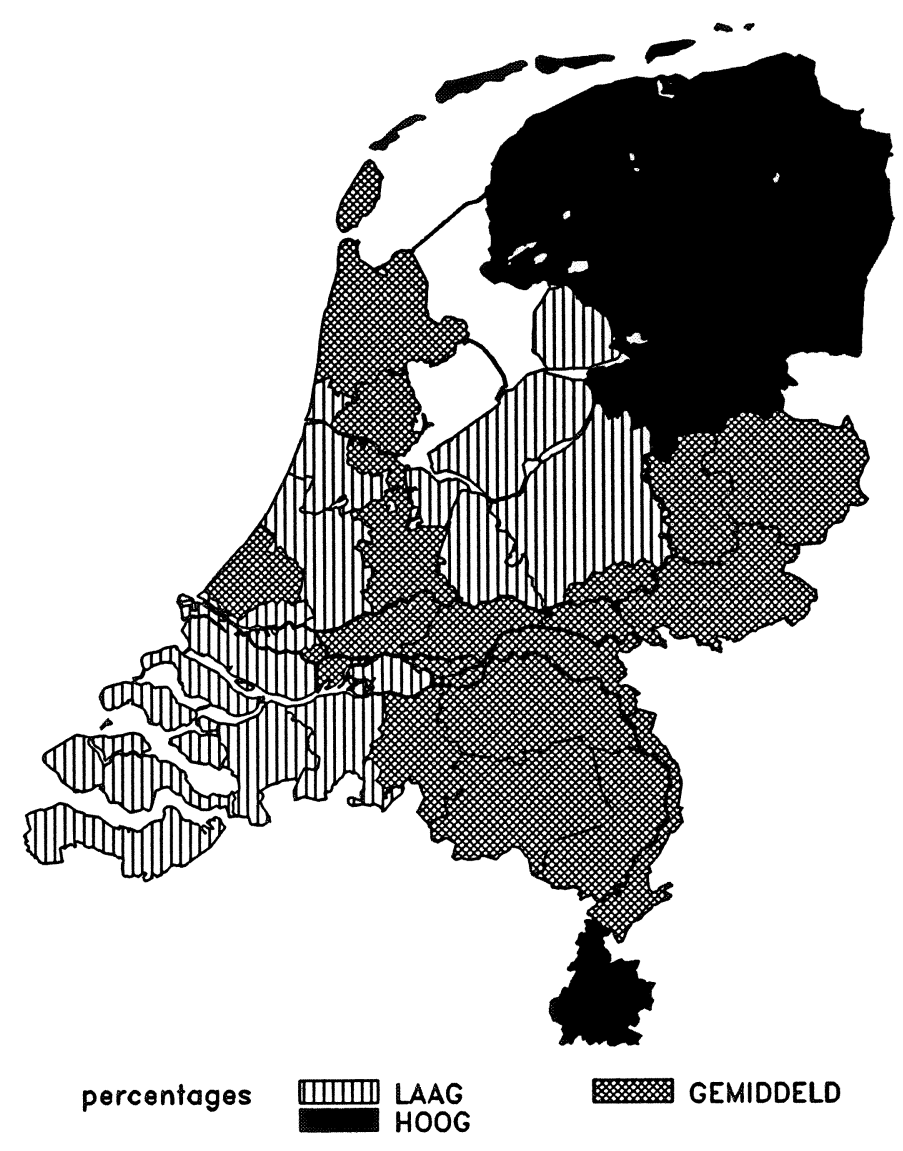

Ten opzichte van de andere opleidingstypen is de landelijke werkloosheid onder schoolverlaters die een opleiding in het middelbaar technisch onderwijs hebben gevolgd relatief laag. Wanneer op basis van het landelijke werkloosheidspercentage de verschillende RBA-gebieden met elkaar worden vergeleken, zien we dat met name in Groningen, Friesland, Drenthe, IJssel-Vecht en Zuid-Limburg, de werkloosheid relatief hoog is ten opzichte van de landelijke werkloosheid onder schoolverlaters van dit opleidingstype. Daarentegen is er sprake van een relatief laag werkloosheidspercentage onder schoolverlaters met deze opleidingsachtergrond in Flevoland, Veluwe, Gooi en Vechtstreek, Oost-Utrecht, Kennemer-, Amstel- en Meerlanden, Rijnstreek, Rijnmond, Zeeland, Westelijk Brabant en Breda en omstreken. Tenslotte is in Noord-Holland Noord, Den Haag/Delft, Midden- en West-Utrecht, de Drechtsteden, Midden- en Noord-Limburg en het oostelijk deel van Gelderland en Brabant sprake van een werkloosheid die ongeveer gelijk is aan het landelijke percentage onder schoolverlaters met deze opleidingsachtergrond. 
Figuur 4.12. MBO Haven en Vervoer

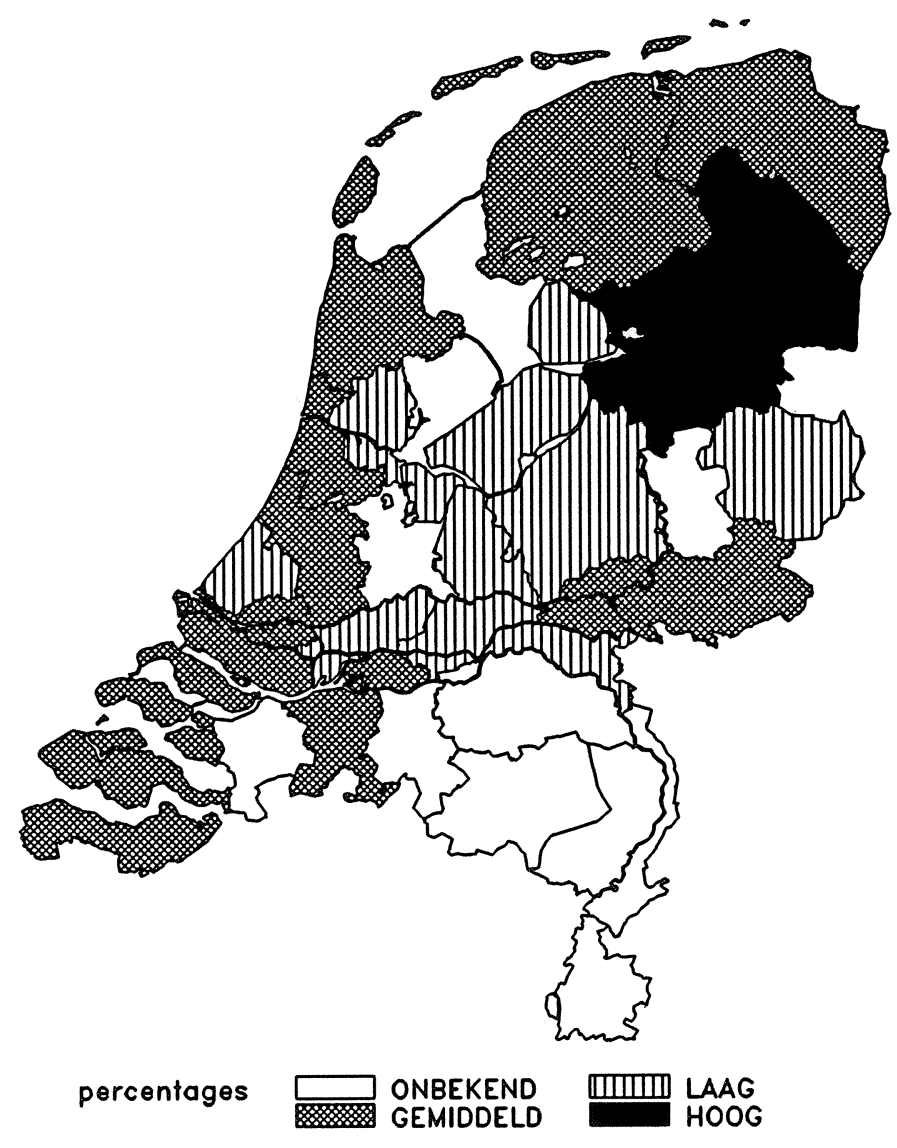

Voor het opleidingstype MBO Haven en vervoer is het landelijke werkloosheidspercentage relatief erg laag vergeleken met de overige opleidingstypen. Voordat de verschillende RBAgebieden met elkaar worden vergeleken, moet worden opgemerkt dat voor vrijwel geheel NoordBrabant en Limburg, met uitzondering van Breda en omstreken, Midden- en West Utrecht en Midden-IJssel de uitstroom uit het onderwijs op minder dan 10 personen wordt geschat. Bij het vergelijken van de RBA-gebieden valt het op dat Drenthe en IJssel-Vecht worden gekenmerkt door een relatief hoge werkloosheid, terwijl Twente, Flevoland, Veluwe, Amsterdam/Zaanstreek/Waterland, Gooi en Vechtstreek, Oost-Utrecht, Den Haag/Delft, Drechtsteden en Nijmegen/Rivierenland een relatief lage werkloosheid laten zien. Voor het noorden van het land en de kustprovincies, met uitzondering van Den Haag/Delft, en Arnhem/Oost-Gelderland is de werkloosheid onder schoolverlaters ongeveer gelijk aan het landelijke werkloosheidspercentage voor schoolverlaters met deze opleidingsachtergrond. 
Figuur 4.13. MBO Medisch Laboratorium

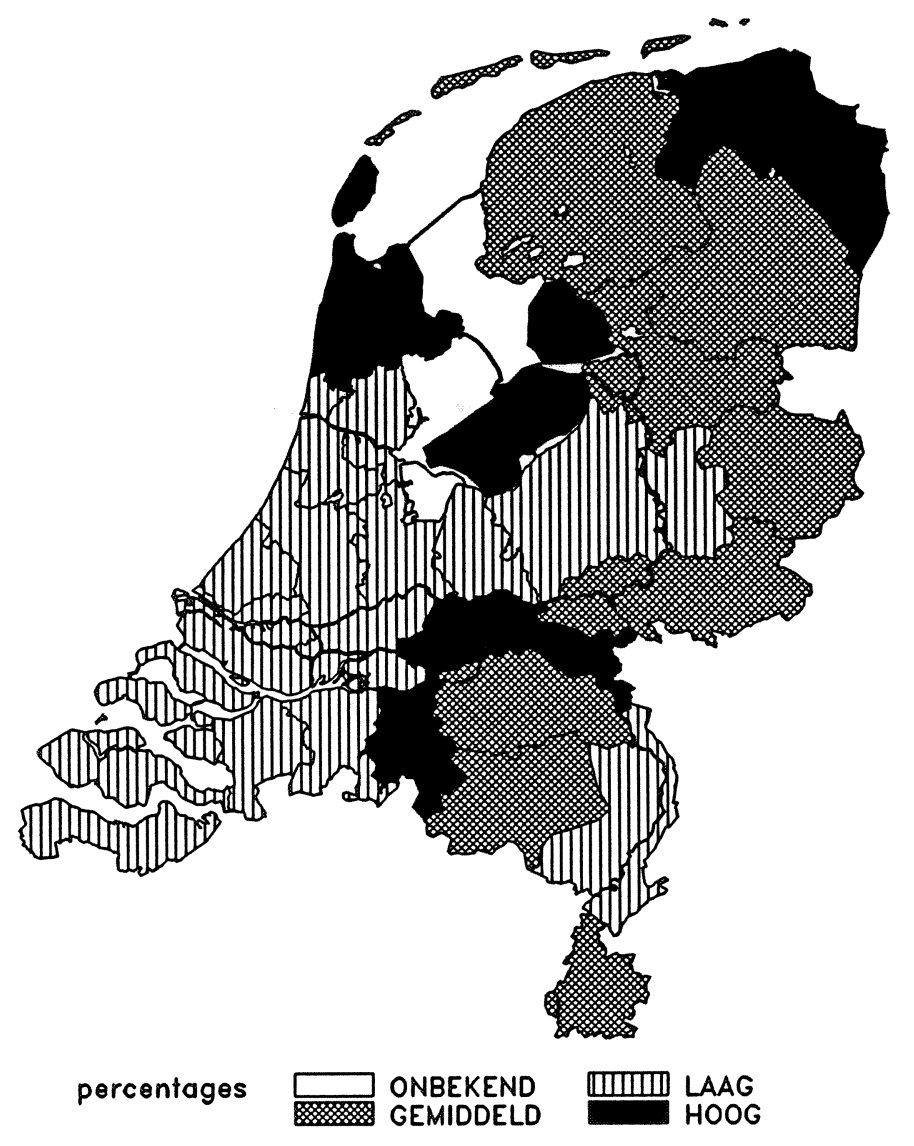

Het middelbaar medisch laboratorium onderwijs wordt gekenmerkt door een landelijke werkloosheid onder schoolverlaters die ongeveer gelijk is aan het gemiddelde van de werkloosheidspercentages van alle onderscheiden opleidingstypen. Wanneer de verschillende RBA-gebieden op basis van het landelijke werkloosheidspercentage onder schoolverlaters met elkaar worden vergeleken valt het volgende op. In een vijftal RBA-gebieden is de werkloosheid onder schoolverlaters relatief hoog ten opzichte van de landelijke werkloosheid onder schoolverlaters met deze opleidingsachtergrond, namelijk Groningen, Flevoland, Noord-Holland Noord, Nijmegen/Rivierenland en Midden-Brabant. De werkloosheid in Friesland, Drenthe, IJsselVecht, Twente, Arnhem/Oost-Gelderland, Noord-Oost en Zuid-Oost Brabant en Zuid-Limburg verschilt niet veel van het landelijke werkloosheidspercentage voor dit opleidingstype. Voor het midden en westen van het land en voor Midden- en Noord-Limburg gelden daarentegen relatief lage werkloosheidspercentages. Tenslotte moet worden opgemerkt dat in het Gooi en de Vechtstreek het aantal van schoolverlaters op minder dan 10 wordt geraamd; derhalve wordt voor deze regio geen werkloosheidspercentage gepresenteerd. 
Figuur 4.14. MBO Verpleging en Ziekenverzorging

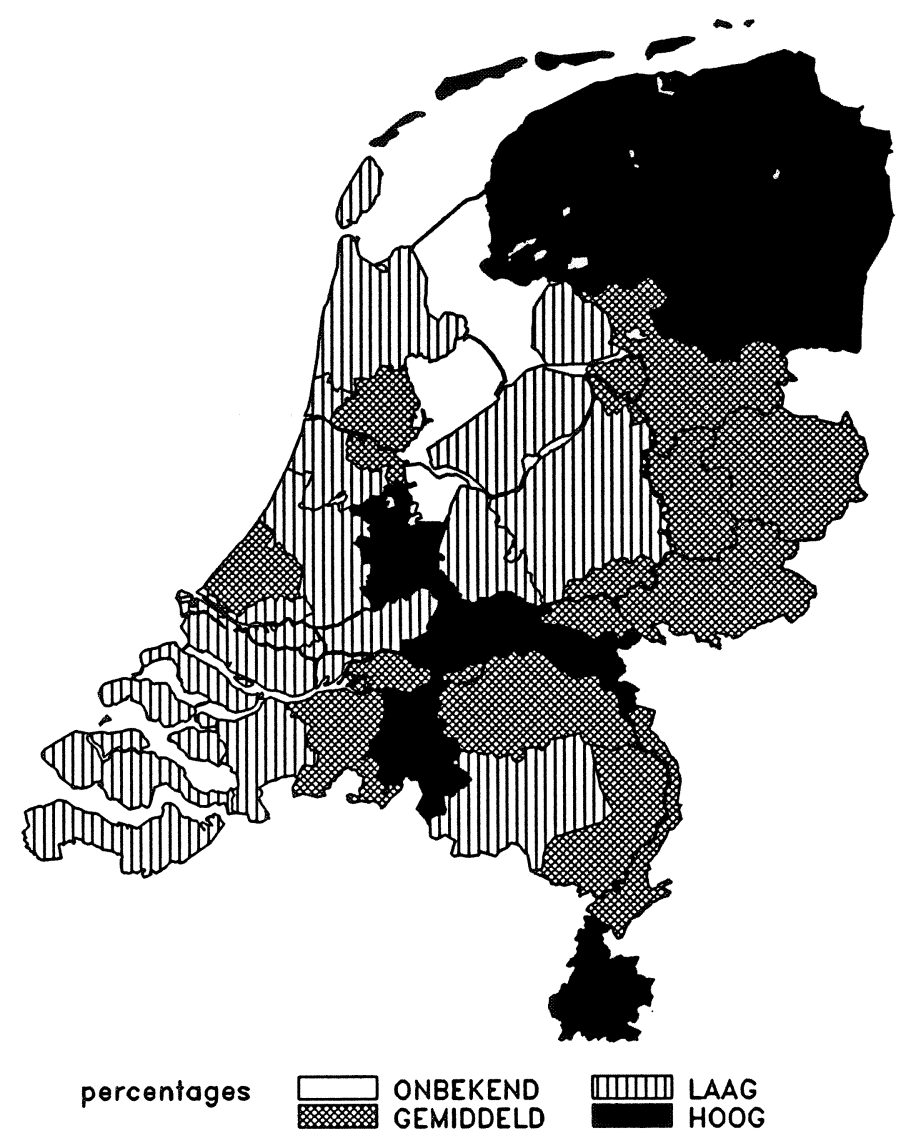

De landelijke werkloosheid onder schoolverlaters voor het opleidingstype MBO Verpleging en ziekenverzorging is relatief laag ten opzichte van de werkloosheidspercentages voor schoolverlaters van de andere opleidingstypen. $O p$ basis van het landelijke werkloosheidspercentage van dit opleidingstype worden de RBA-gebieden met elkaar vergeleken. Daarbij valt het op dat de drie noordelijke provincies, Nijmegen/Rivierenland en Midden- en West-Utrecht, Midden-Brabant en Zuid-Limburg worden gekenmerkt door relatief hoge werkloosheidscijfers. De RBA-regio's in het westen, Noord-Holland Noord, Kennemer-, Amstel- en Meerlanden, Rijnstreek, Drechtsteden, Rijnmond, Zeeland, Westelijk Brabant, en Flevoland, Veluwe, Oost-Utrecht en Zuid-Oost Brabant worden daarentegen gekenmerkt door een relatief laag werkloosheidspercentage. In Amsterdam/Zaanstreek/Waterland, Den Haag/Delft, Breda en omstreken en een aantal oostelijk RBA-gebieden zijn de werkloosheidspercentages onder schoolverlaters ongeveer gelijk aan het landelijke werkloosheidspercentage onder schoolverlaters met deze opleidingsachtergrond. Voor de RBAregio Gooi en Vechtstreek wordt geen werkloosheidspercentage gepresenteerd, omdat het aantal schoolverlaters in deze opleidingscategorie op minder dan 10 wordt geschat. 
Figuur 4.15. MBO Economisch-Administratief

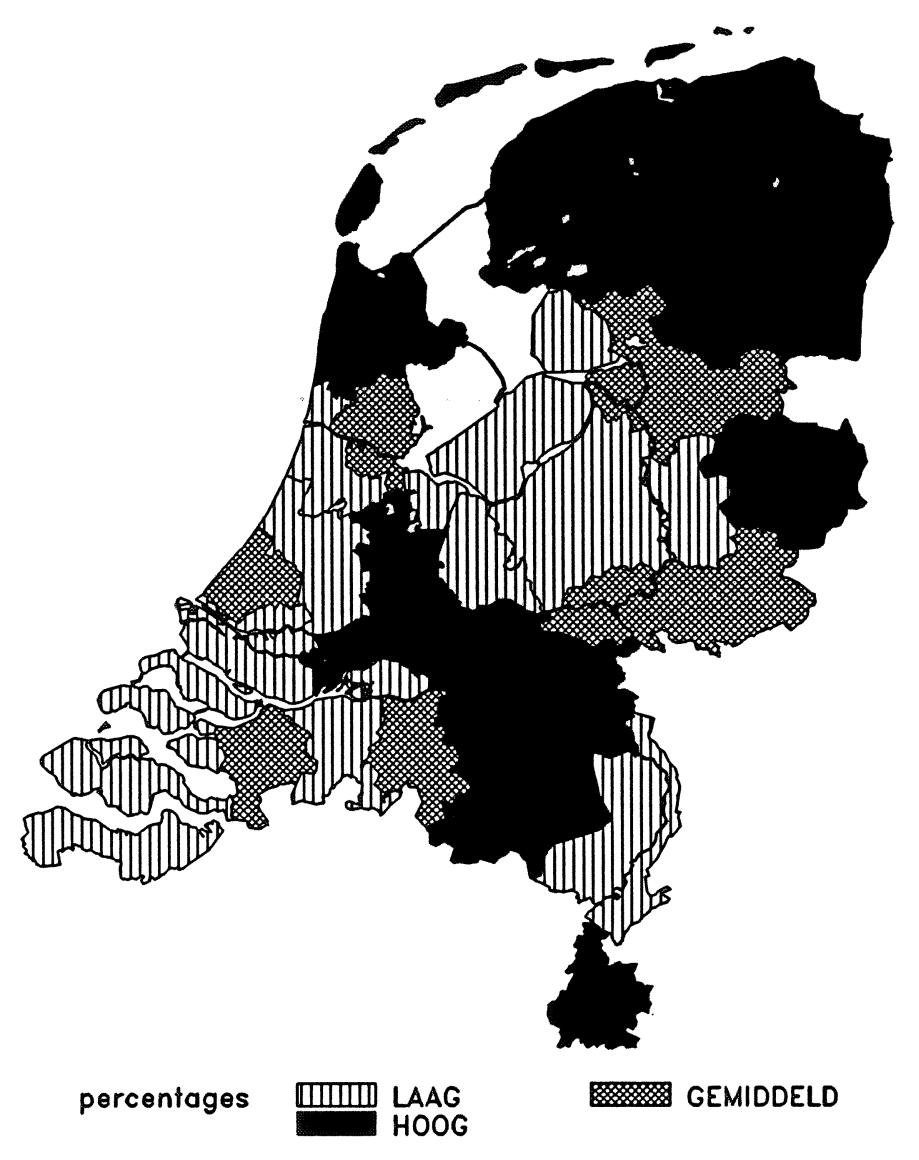

Voor schoolverlaters met een opleiding in het middelbaar economisch en administratief onderwijs, is het landelijke werkloosheidspercentage ongeveer gelijk aan het gemiddelde werkloosheidspercentage voor schoolverlaters over alle onderscheiden opleidingstypen. Ook voor dit opleidingstype zijn de regionale werkloosheidspercentages onder schoolverlaters vergeleken met het landelijke percentage voor schoolverlaters. Daarbij valt het op dat in Groningen, Friesland, Drenthe, Twente, Noord-Holland Noord, Midden- en West-Utrecht, Drechtsteden, Nijmegen/Rivierenland en Noord-Oost en Zuid-Oost Brabant en Zuid Limburg de werkloosheid hoger is dan het landelijke werkloosheidspercentage onder schoolverlaters met deze opleidingsachtergrond. Daarentegen is de werkloosheid in Flevoland, Midden-IJssel, Veluwe, Oost-Utrecht, Gooi en Vechtstreek, Kennemer-, Amstel- en Meerlanden, de Rijnstreek, de Rijnmond, Zeeland, Breda en omstreken en Midden- en Noord-Limburg relatief laag ten opzichte van de landelijke werkloosheid onder schoolverlaters. Tenslotte worden IJssel-Vecht, Amsterdam/Zaanstreek/Waterland, Den Haag/Delft, Arnhem/Oost-Gelderland, Westelijk Brabant en Midden-Brabant gekenmerkt door een werkloosheid die niet veel verschilt van de landelijke werkloosheid onder schoolverlaters. 
Figuur 4.16. MBO Bestuurlijk

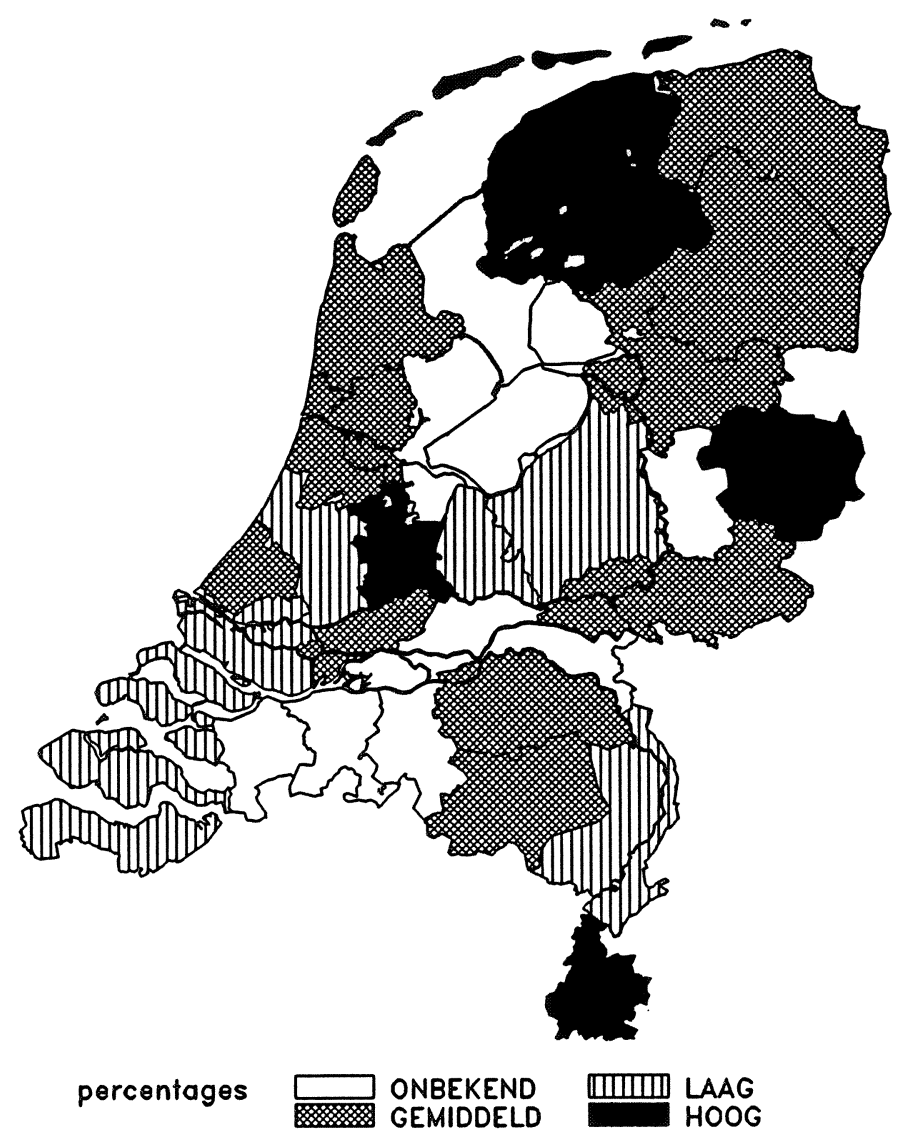

Het middelbaar bestuurlijk onderwijs wordt gekenmerkt door een landelijk werkloosheidspercentage dat ongeveer gelijk is aan het gemiddelde van de percentages werkloze schoolverlaters over alle onderscheiden opleidingstypen. In met name een aantal zuidelijke RBA-gebieden, Nijmegen/Rivierenland, Westelijk Brabant, Breda en omstreken en Midden-Brabant, en MiddenIJssel, Flevoland en Gooi en Vechtstreek wordt de uitstroom uit het onderwijs op minder dan 10 geschat. Wanneer we de verschillende RBA-gebieden met elkaar vergelijken op basis van het landelijke werkloosheidspercentage onder schoolverlaters met dit opleidingstype, valt op dat in Friesland, Twente, Midden- en West Utrecht en Zuid-Limburg de werkloosheid relatief hoog is ten opzichte van het landelijke percentage. Voor de Veluwe, Oost-Utrecht, Rijnstreek, Rijnmond, Zeeland en Midden- en Noord-Limburg is de werkloosheid onder schoolverlaters met deze opleidingsachtergrond daarentegen relatief laag. Tenslotte gelden voor Groningen, Drenthe, IJssel-Vecht, Arnhem/Oost-Gelderland, Noord-Holland Noord, Amsterdam/Zaanstreek/Waterland, Kennemer-, Amstel- en Meerlanden, Den Haag/Delft en Noord-Oost en Zuid-Oost Brabant werkloosheidspercentages die overeenkomen met de landelijke werkloosheid onder schoolverlaters. 
Figuur 4.17. MBO Sociaal-Cultureel

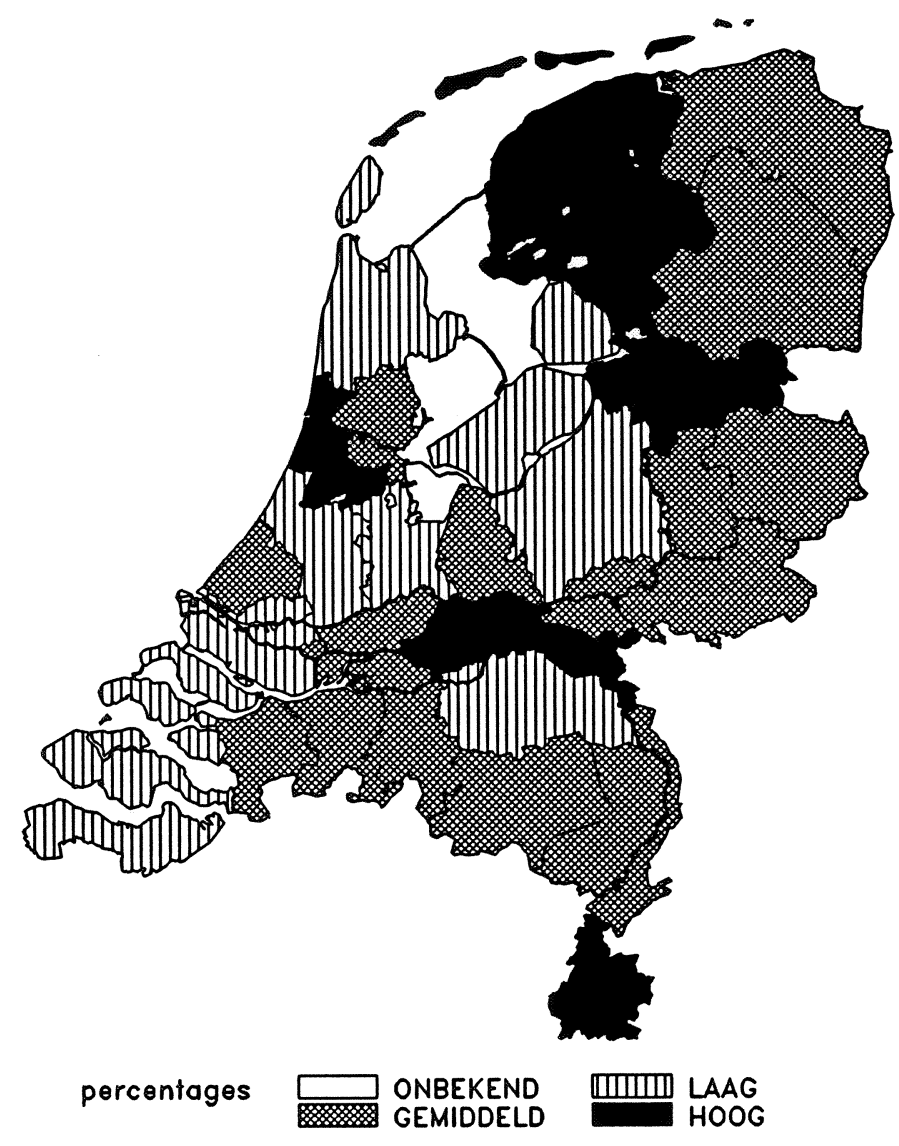

De landelijke werkloosheid voor schoolverlaters die een sociaal-culturele opleiding op middelbaar niveau hebben afgerond, is relatief hoog ten opzichte van de werkloosheidspercentages van de overige onderscheiden opleidingstypen. Bij het vergelijken van de regionale werkloosheidspercentages met het landelijke werkloosheidspercentage valt het volgende op. In Friesland, IJsselVecht, Kennemer-, Amstel- en Meerlanden, Nijmegen/Rivierenland en Zuid-Limburg gelden relatief hoge werkloosheidscijfers. Daarentegen is de-werkloosheid voor Flevoland, Veluwe, Noord-Holland Noord, Midden- en West-Utrecht, Rijnstreek, Rijnmond, Zeeland en Noord-Oost Brabant relatief laag te noemen ten opzichte van de landelijke werkloosheid onder schoolverlaters met dit opleidingstype. Een werkloosheid die niet veel afwijkt van het landelijke percentage komt voor in Groningen, Drenthe, Twente, Midden-IJssel, Arnhem/Oost-Gelderland, Oost-Utrecht, Amsterdam/Zaanstreek/Waterland, Den Haag/Delft, de Drechtsteden, Brabant met uitzondering van Noord-Oost Brabant en Midden- en Noord-Limburg. Tenslotte moet worden opgemerkt dat in het Gooi en de Vechtstreek de uitstroom van gediplomeerden naar de arbeidsmarkt op minder dan 10 wordt geraamd; derhalve wordt voor deze regio geen werkloosheidspercentage gepresenteerd. 
Figuur 4.18. MBO Verzorging

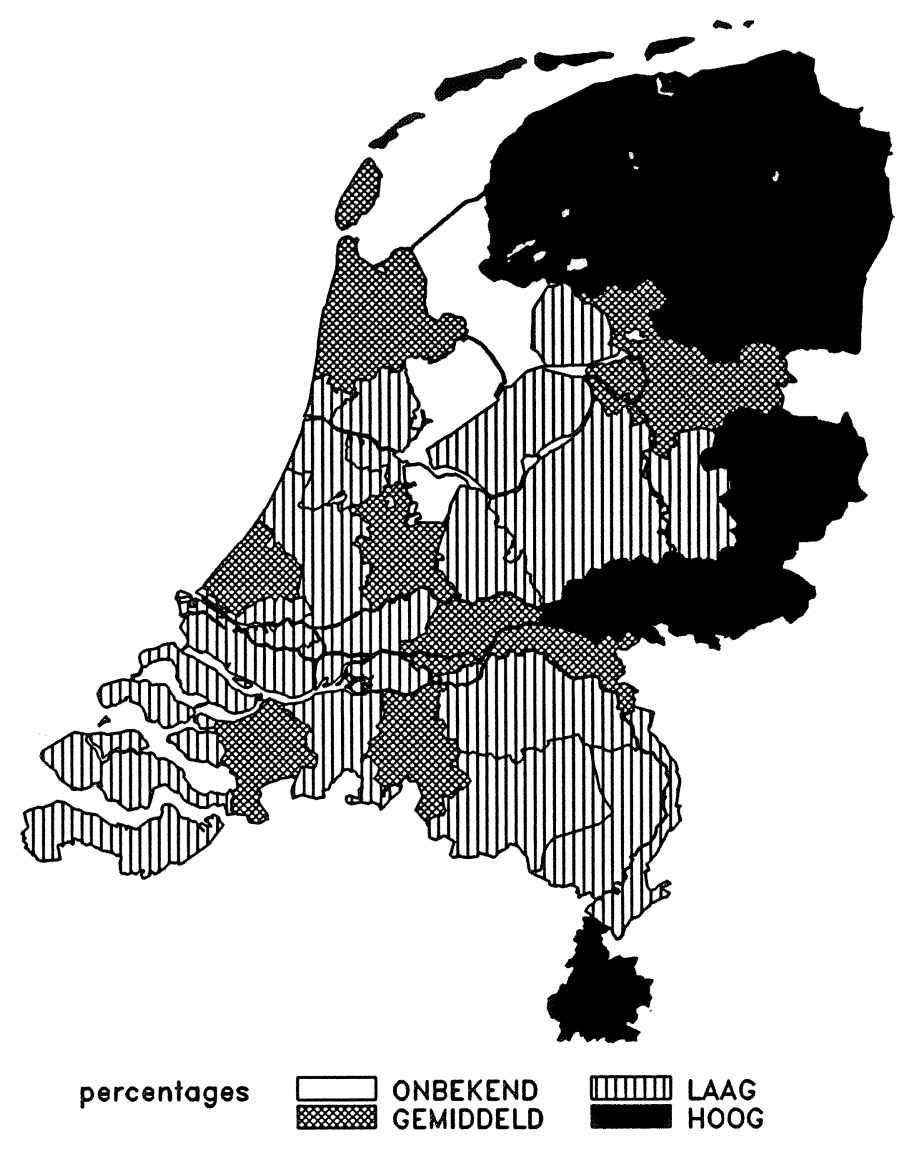

Van de schoolverlaters die een opleiding MBO Verzorging hebben afgerond, is in vergelijking met de schoolverlaters van andere opleidingstypen, een relatief hoog percentage werkloos. Indien de regionale werkloosheid wordt vergeleken met de landelijke werkloosheid onder schoolverlaters voor dit opleidingstype valt het volgende op. Groningen, Friesland, Drenthe, Twente, Arnhem/Oost-Gelderland en Zuid-Limburg worden gekenmerkt door een relatief hoog werkloosheidspercentage ten opzichte van de landelijke werkloosheid onder schoolverlaters met deze opleidingsachtergrond. In IJssel-Vecht, Midden- en West-Utrecht, Noord-Holland Noord, Den Haag/Delft, Nijmegen/Rivierenland, Westelijk Brabant en Midden-Brabant is de werkloosheid ongeveer gelijk aan het landelijke werkloosheidspercentage onder schoolverlaters met deze opleidingsachtergrond. De overige RBA-gebieden, voornamelijk in het westen en midden van het land, vertonen een relatief lage werkloosheid. Tenslotte geldt ook voor dit opleidingstype dat de instroom van schoolverlaters op de arbeidsmarkt voor het RBA-gebied Gooi en Vechtstreek op minder dan 10 wordt geraamd; derhalve wordt er voor deze regio geen werkloosheidspercentage gepresenteerd. 


\section{$-37$}

Tabel 4.1. Regionale werkloosheidspercentages onder schoolverlaters per RBA-gebied

\begin{tabular}{lll}
\hline opleiding & werkloosheidspercentage & typering \\
\hline
\end{tabular}

\section{MAVO en onderbouw HAVONWO}

\begin{tabular}{ll}
1 & Groningen \\
2 & Friesland \\
3 & Drenthe \\
4 & IJssel-Vecht \\
5 & Twente \\
6 & Midden-IJssel \\
7 & Veluwe \\
8 & Arnhem/Oost-Gelderland \\
9 & Nijmegen/Rivierenland \\
10 & Flevoland \\
11 & Oost-Utrecht \\
12 & Midden- en West-Utrecht \\
13 & Gooi en Vechtstreek \\
14 & Noord-Holland Noord \\
15 & Amsterdam/Zaanstreek/Waterland \\
16 & Kennemer-/Amstel- en Meerlanden \\
17 & Rijnstreek \\
18 & Den Haag/Delft \\
19 & Drechtsteden \\
20 & Rijnmond \\
21 & Zeeland \\
22 & Westelijk Noord-Brabant \\
23 & Breda en omstreken \\
24 & Midden-Brabant \\
25 & Noord-Oost Brabant \\
26 & Zuid-Oost Brabant \\
27 & Midden- en Noord-Limburg \\
28 & Zuid-Limburg \\
\hline &
\end{tabular}

hoog
gemiddeld
gemiddeld
hoog
hoog
hoog
laag
hoog
hoog
hoog
gemiddeld
gemiddeld
laag
gemiddeld
laag
laag
laag
gemiddeld
gemiddeld
laag
laag
gemiddeld
gemiddeld
hoog
hoog
hoog
gemiddeld
hoog


$-38-$

Tabel 4.2. Regionale werkloosheidspercentages onder schoolverlaters per RBA-gebied

$\begin{array}{lll}\text { opleiding } & \text { werkloosheidspercentage } \quad \text { typering }\end{array}$

\section{LBO Agrarisch}

1 Groningen

2 Friesland

Drenthe

27

24

IJssel-Vecht

15

Twente

10

Midden-IJssel

27

Veluwe

Arnhem/Oost-Gelderland

Nijmegen/Rivierenland

10 Flevoland

1 Oost-Utrecht

12 Midden- en West-Utrecht 11

13 Gooi en Vechtstreek

14 Noord-Holland Noord

15 Amsterdam/Zaanstreek/Waterland

16 Kennemer-/Amstel- en Meerlanden

17 Rijnstreek

18 Den Haag/Delft

19 Drechtsteden

20 Rijnmond

21 Zeeland

22 Westelijk Noord-Brabant

23 Breda en omstreken

24 Midden-Brabant

25 Noord-Oost Brabant

26 Zuid-Oost Brabant

27 Midden- en Noord-Limburg

28 Zuid-Limburg

\author{
hoog \\ hoog \\ gemiddeld \\ gemiddeld \\ hoog \\ gemiddeld \\ gemiddeld \\ gemiddeld \\ hoog \\ gemiddeld \\ laag \\ gemiddeld \\ gemiddeld \\ laag \\ laag \\ laag \\ laag \\ laag \\ hoog \\ laag \\ gemiddeld \\ gemiddeld \\ hoog \\ hoog \\ hoog \\ gemiddeld \\ hoog \\ hoog
}


$-39-$

Tabel 4.3. Regionale werkloosheidspercentages onder schoolverlaters per RBA-gebied

\begin{tabular}{lll}
\hline opleiding & werkloosheidspercentage & typering \\
\hline
\end{tabular}

\section{LBO Technisch}

1 Groningen

2 Friesland

3 Drenthe

4 IJssel-Vecht

5 Twente

6 Midden-IJssel

7 Veluwe

8 Arnhem/Oost-Gelderland

9 Nijmegen/Rivierenland

10 Flevoland

11 Oost-Utrecht

12 Midden- en West-Utrecht

13 Gooi en Vechtstreek

14 Noord-Holland Noord

15 Amsterdam/Zaanstreek/Waterland

16 Kennemer-/Amstel- en Meerlanden

17 Rijnstreek

18 Den Haag/Delft

19 Drechtsteden

20 Rijnmond

21 Zeeland

22 Westelijk Noord-Brabant

23 Breda en omstreken

24 Midden-Brabant

25 Noord-Oost Brabant

26 Zuid-Oost Brabant

27 Midden- en Noord-Limburg

28 Zuid-Limburg

\begin{tabular}{l} 
hoog \\
hoog \\
gemiddeld \\
laag \\
hoog \\
gemiddeld \\
laag \\
gemiddeld \\
hoog \\
laag \\
laag \\
gemiddeld \\
laag \\
gemiddeld \\
laag \\
laag \\
laag \\
hoog \\
gemiddeld \\
laag \\
laag \\
gemiddeld \\
gemiddeld \\
gemiddeld \\
laag \\
laag \\
laag \\
hoog \\
\hline
\end{tabular}

hoog

11

10

5

11

9

4

9

11

5

4

8

4

6

5

3

2

17

7

5

3

6

7

10

5

5

4

16 
$-40-$

Tabel 4.4. Regionale werkloosheidspercentages onder schoolverlaters per RBA-gebied

$\begin{array}{lll}\text { opleiding } \quad \text { werkloosheidspercentage } & \text { typering }\end{array}$

\section{LBO Haven \& Vervoer}

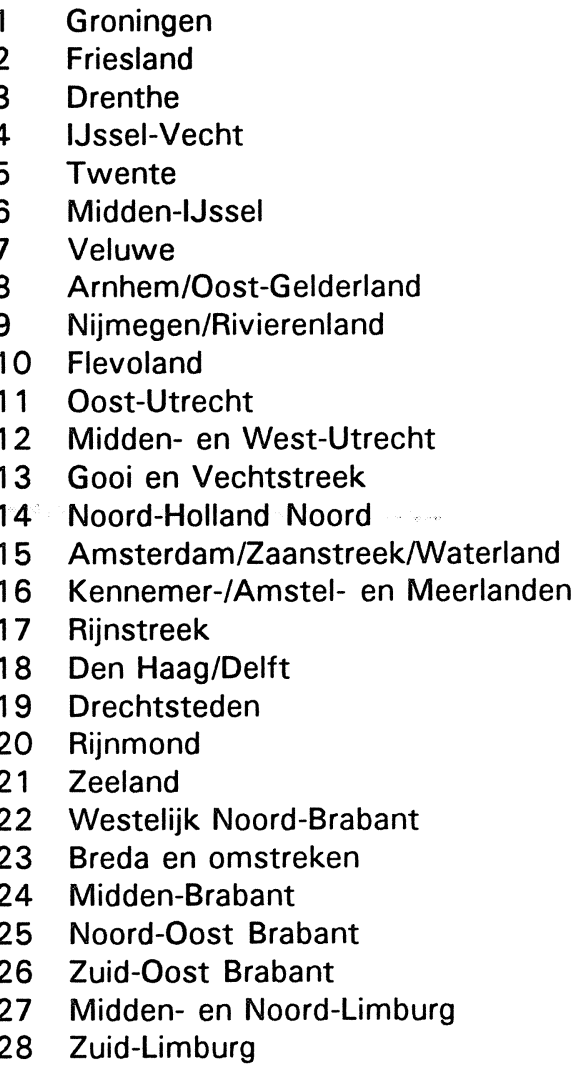

8 Zuid-Limburg

\begin{aligned} 18 & hoog \\ 0 & laag \\ - & \\ - & \\ - & \\ - & \\ - & \\ - & \\ - & \\ 0 & \\ - & laag \\ - & \\ - & \\ 3 & \\ 0 & \\ 7 & laagiddeld \\ 0 & hoog \\ - & laag \\ - & \\ 2 & laag \\ 48 & hoog \\ - & \\ - & \\ - & \\ - & \\ - & \\ - & \\ \hline & \end{aligned}


Tabel 4.5. Regionale werkloosheidspercentages onder schoolverlaters per RBA-gebied

\begin{tabular}{lll}
\hline opleiding & werkloosheidspercentage & typering \\
\hline
\end{tabular}

\section{LBO Economisch-Administratief}

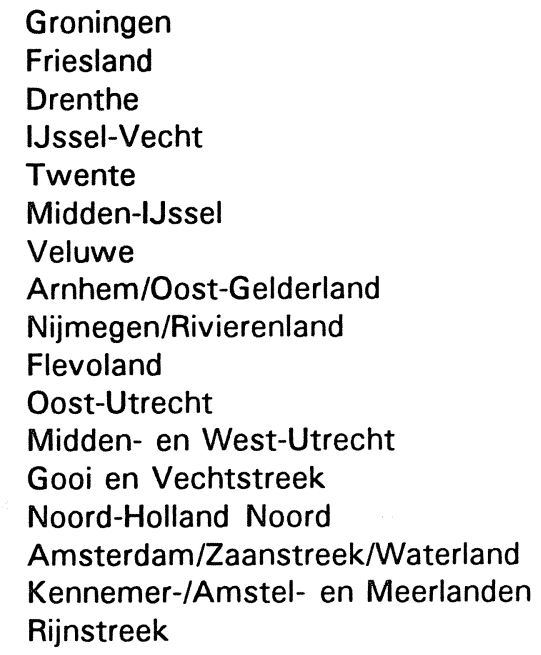

Noord-Holland Noord

Amsterdam/Zaanstreek/Waterland

Kennemer-/Amstel- en Meerlanden

Rijnstreek

Den Haag/Delft $\quad 37$

Drechtsteden 26

20 Rijnmond 28

21 Zeeland 27

22 Westelijk Noord-Brabant $\quad 42$

23 Breda en omstreken 23

24 Midden-Brabant $\quad 35$

25 Noord-Oost Brabant 26

26 Zuid-Oost Brabant 29

27 Midden- en Noord-Limburg 50

28 Zuid-Limburg

hoog

hoog

gemiddeld

laag

hoog

hoog

laag

gemiddeld

hoog

gemiddeld

gemiddeld

gemiddeld

laag

gemiddeld

laag

laag

laag

gemiddeld

gemiddeld

gemiddeld

gemiddeld

hoog

laag

gemiddeld

gemiddeld

gemiddeld

hoog

gemiddeld 
Tabel 4.6. Regionale werkloosheidspercentages onder schoolverlaters per RBA-gebied

\begin{tabular}{lll}
\hline opleiding & werkloosheidspercentage & typering \\
\hline
\end{tabular}

\section{7. $L B O$ Verzorgend}

$\begin{array}{lcl}\text { Groningen } & 31 & \text { hoog } \\ \text { Friesland } & 29 & \text { hoog } \\ \text { Drenthe } & 15 & \text { laag } \\ \text { IJssel-Vecht } & 22 & \text { gemiddeld } \\ \text { Twente } & 35 & \text { hoog } \\ \text { Midden-IJssel } & 26 & \text { hoog } \\ \text { Veluwe } & 15 & \text { laag } \\ \text { Arnhem/Oost-Gelderland } & 16 & \text { gemiddeld } \\ \text { Nijmegen/Rivierenland } & 44 & \text { hoog } \\ \text { Flevoland } & 24 & \text { gemiddeld } \\ \text { Oost-Utrecht } & 15 & \text { laag } \\ \text { Midden- en West-Utrecht } & 14 & \text { laag } \\ \text { Gooi en Vechtstreek } & 19 & \text { gemiddeld } \\ \text { Noord-Holland Noord } & 21 & \text { gemiddeld } \\ \text { Amsterdam/Zaanstreek/Waterland } & 7 & \text { laag } \\ \text { Kennemer-/Amstel- en Meerlanden } & 10 & \text { laag } \\ \text { Rijnstreek } & 8 & \text { laag } \\ \text { Den Haag/Delft } & 17 & \text { gemiddeld } \\ \text { Drechtsteden } & 28 & \text { hoog } \\ \text { Rijnmond } & 13 & \text { laag } \\ \text { Zeeland } & 14 & \text { laag } \\ \text { Westelijk Noord-Brabant } & 17 & \text { gemiddeld } \\ \text { Breda en omstreken } & 18 & \text { gemiddeld } \\ \text { Midden-Brabant } & 30 & \text { hoog } \\ \text { Noord-Oost Brabant } & 20 & \text { gemiddeld } \\ \text { Zuid-Oost Brabant } & 15 & \text { laag } \\ \text { Midden- en Noord-Limburg } & 20 & \text { gemiddeld } \\ \text { Zuid-Limburg } & 34 & \text { hoog } \\ \end{array}$


$-43-$

Tabel 4.7. Regionale werkloosheidspercentages onder schoolverlaters per RBA-gebied opleiding

werkloosheidspercentage

typering

10. Bovenbouw HAVONWO

$\begin{array}{ll}1 & \text { Groningen } \\ 2 & \text { Friesland } \\ 3 & \text { Drenthe } \\ 4 & \text { IJssel-Vecht } \\ 5 & \text { Twente } \\ 6 & \text { Midden-IJssel } \\ 7 & \text { Veluwe } \\ 8 & \text { Arnhem/Oost-Gelderland } \\ 9 & \text { Nijmegen/Rivierenland } \\ 10 & \text { Flevoland } \\ 11 & \text { Oost-Utrecht } \\ 12 & \text { Midden- en West-Utrecht } \\ 13 & \text { Gooi en Vechtstreek } \\ 14 & \text { Noord-Holland Noord } \\ 15 & \text { Amsterdam/Zaanstreek/Waterland } \\ 16 & \text { Kennemer-/Amstel- en Meerlanden } \\ 17 & \text { Rijnstreek } \\ 18 & \text { Den Haag/Delft } \\ 19 & \text { Drechtsteden } \\ 20 & \text { Rijnmond } \\ 21 & \text { Zeeland } \\ 22 & \text { Westelijk Noord-Brabant } \\ 23 & \text { Breda en omstreken } \\ 24 & \text { Midden-Brabant } \\ 25 & \text { Noord-Oost Brabant } \\ 26 & \text { Zuid-Oost Brabant } \\ 27 & \text { Midden- en Noord-Limburg } \\ 28 & \text { Zuid-Limburg } \\ & \end{array}$

97

52

19

29

32

37

20

27

65

13

18

49

11

15

26

14

18

36

15

14

10

17

23

51

21

43

22

69

\author{
hoog \\ hoog \\ gemiddeld \\ gemiddeld \\ gemiddeld \\ gemiddeld \\ gemiddeld \\ gemiddeld \\ hoog \\ laag \\ gemiddeld \\ hoog \\ laag \\ laag \\ gemiddeld \\ laag \\ gemiddeld \\ gemiddeld \\ laag \\ laag \\ laag \\ laag \\ gemiddeld \\ hoog \\ gemiddeld \\ hoog \\ gemiddeld \\ hoog
}


$-44-$

Tabel 4.8. Regionale werkloosheidspercentages onder schoolverlaters per RBA-gebied

\begin{tabular}{lll}
\hline opleiding & werkloosheidspercentage & typering
\end{tabular}

\section{MBO Agrarisch}

$\begin{array}{ll}1 & \text { Groningen } \\ 2 & \text { Friesland } \\ 3 & \text { Drenthe } \\ 4 & \text { IJssel-Vecht } \\ 5 & \text { Twente } \\ 6 & \text { Midden-IJssel } \\ 7 & \text { Veluwe } \\ 8 & \text { Arnhem/Oost-Gelderland } \\ 9 & \text { Nijmegen/Rivierenland } \\ 10 & \text { Flevoland } \\ 11 & \text { Oost-Utrecht } \\ 12 & \text { Midden- en West-Utrecht } \\ 13 & \text { Gooi en Vechtstreek } \\ 14 & \text { Noord-Holland Noord } \\ 15 & \text { Amsterdam/Zaanstreek/Waterland } \\ 16 & \text { Kennemer-/Amstel- en Meerlanden } \\ 17 & \text { Rijnstreek } \\ 18 & \text { Den Haag/Delft } \\ 19 & \text { Drechtsteden } \\ 20 & \text { Rijnmond } \\ 21 & \text { Zeeland } \\ 22 & \text { Westelijk Noord-Brabant } \\ 23 & \text { Breda en omstreken } \\ 24 & \text { Midden-Brabant } \\ 25 & \text { Noord-Oost Brabant } \\ 26 & \text { Zuid-Oost Brabant } \\ 27 & \text { Midden- en Noord-Limburg } \\ 28 & \text { Zuid-Limburg } \\ & \end{array}$

hoog
hoog
gemiddeld
hoog
hoog
hoog
laag
laag
hoog
laag
laag
gemiddeld
gemiddeld
laag
hoog
gemiddeld
laag
gemiddeld
gemiddeld
gemiddeld
laag
laag
gemiddeld
gemiddeld
laag
laag
laag
gemiddeld


$-45-$

Tabel 4.9. Regionale werkloosheidspercentages onder schoolverlaters per RBA-gebied opleiding

12. MBO Technisch Laboratorium

1 Groningen

2 Friesland

3 Drenthe

4 IJssel-Vecht

5 Twente

Midden-IJssel

Veluwe

Arnhem/Oost-Gelderland

Nijmegen/Rivierenland

10 Flevoland

11 Oost-Utrecht

12 Midden- en West-Utrecht

13 Gooi en Vechtstreek

14 Noord-Holland Noord

15 Amsterdam/Zaanstreek/Waterland

16 Kennemer-/Amstel- en Meerlanden

17 Rijnstreek

18 Den Haag/Delft

19 Drechtsteden

20 Rijnmond

21 Zeeland

22 Westelijk Noord-Brabant

23 Breda en omstreken

24 Midden-Brabant

25 Noord-Oost Brabant

26 Zuid-Oost Brabant

27 Midden- en Noord-Limburg

28 Zuid-Limburg

hoog

laag

laag

hoog

laag

laag

gemiddeld 
$-46-$

Tabel 4.10. Regionale werkloosheidspercentages onder schoolverlaters per RBA-gebied

opleiding $\quad$ werkloosheidspercentage $\quad$ typering

\section{MBO Technisch}

$\begin{array}{llrl}1 & \text { Groningen } & 20 & \text { hoog } \\ 2 & \text { Friesland } & 19 & \text { hoog } \\ 3 & \text { Drenthe } & 15 & \text { hoog } \\ 4 & \text { IJssel-Vecht } & 19 & \text { hoog } \\ 5 & \text { Twente } & 12 & \text { gemiddeld } \\ 6 & \text { Midden-IJssel } & 7 & \text { gemiddeld } \\ 7 & \text { Veluwe } & 5 & \text { laag } \\ 8 & \text { Arnhem/Oost-Gelderland } & 10 & \text { gemiddeld } \\ 9 & \text { Nijmegen/Rivierenland } & 12 & \text { gemiddeld } \\ 10 & \text { Flevoland } & 4 & \text { laag } \\ 11 & \text { Oost-Utrecht } & 3 & \text { laag } \\ 12 & \text { Midden- en West-Utrecht } & 11 & \text { gemiddeld } \\ 13 & \text { Gooi en Vechtstreek } & 4 & \text { laag } \\ 14 & \text { Noord-Holland Noord } & 9 & \text { gemiddeld } \\ 15 & \text { Amsterdam/Zaanstreek/Waterland } & 9 & \text { gemiddeld } \\ 16 & \text { Kennemer-IAmstel- en Meerlanden } & 9 & \text { laag } \\ 17 & \text { Rijnstreek } & 3 & \text { laag } \\ 18 & \text { Den Haag/Delft } & 4 & \text { gemiddeld } \\ 19 & \text { Drechtsteden } & 9 & \text { gemiddeld } \\ 20 & \text { Rijnmond } & 9 & \text { laag } \\ 21 & \text { Zeeland } & 8 & \text { laag } \\ 22 & \text { Westelijk Noord-Brabant } & 5 & \text { laag } \\ 23 & \text { Breda en omstreken } & 5 & \text { laag } \\ 24 & \text { Midden-Brabant } & 2 & \text { gemiddeld } \\ 25 & \text { Noord-Oost Brabant } & 2 & \text { gemiddeld } \\ 26 & \text { Zuid-Oost Brabant } & \text { gemiddeld } \\ 27 & \text { Midden- en Noord-Limburg } & 2 & \text { gemiddeld } \\ 28 & \text { Zuid-Limburg } & 5 & \text { hoog }\end{array}$


$-47-$

Tabel 4.11. Regionale werkloosheidspercentages onder schoolverlaters per RBA-gebied opleiding

werkloosheidspercentage

typering

14. MBO Haven \& Vervoer

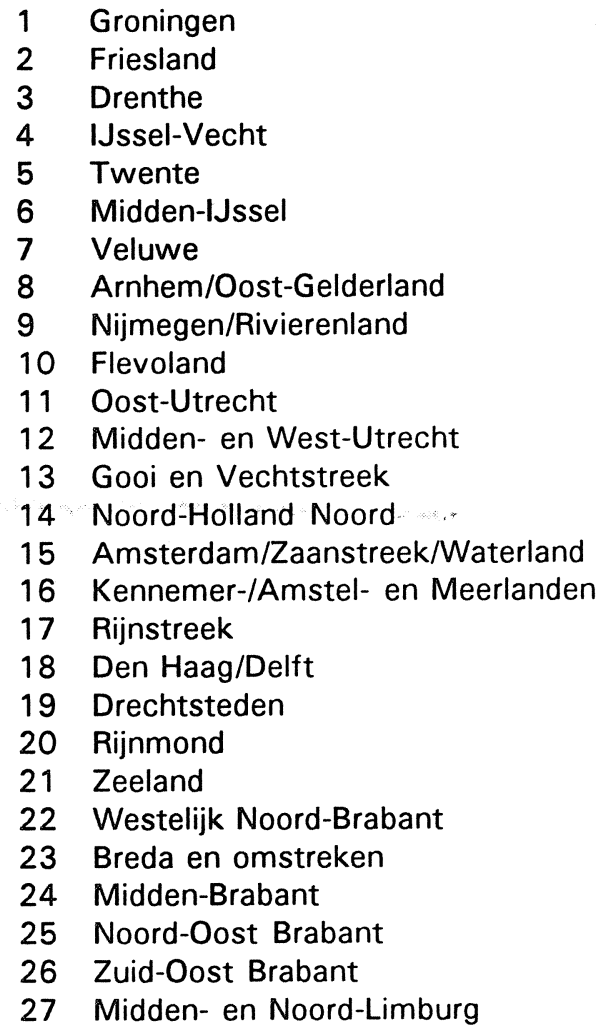

\author{
gemiddeld \\ gemiddeld \\ hoog \\ hoog \\ laag \\ laag \\ gemiddeld \\ laag \\ laag \\ laag \\ laag \\ gemiddeld \\ laag \\ gemiddeld \\ gemiddeld \\ laag \\ laag \\ gemiddeld \\ gemiddeld \\ gemiddeld
}


$-48-$

Tabel 4.12. Regionale werkloosheidspercentages onder schoolverlaters per RBA-gebied

\begin{tabular}{lll}
\hline opleiding & werkloosheidspercentage & typering \\
\hline
\end{tabular}

15. MBO Medisch Laboratorium

1 Groningen

2 Friesland

3 Drenthe

4 IJssel-Vecht

5 Twente

6 Midden-IJssel

7 Veluwe

8 Arnhem/Oost-Gelderland

9 Nijmegen/Rivierenland

10 Flevoland

11 Oost-Utrecht

12 Midden- en West-Utrecht

13 Gooi en Vechtstreek

14 Noord-Holland Noord

15 Amsterdam/Zaanstreek/Waterland

16 Kennemer-/Amstel- en Meerlanden

17 Rijnstreek

18 Den Haag/Delft

19 Drechtsteden

20 Rijnmond

21 Zeeland

22 Westelijk Noord-Brabant

23 Breda en omstreken

24 Midden-Brabant

25 Noord-Oost Brabant

26 Zuid-Oost Brabant

27 Midden- en Noord-Limburg

28 Zuid-Limburg

hoog
gemiddeld
gemiddeld
gemiddeld
gemiddeld
laag
laag
gemiddeld
hoog
hoog
laag
laag
hoog
laag
laag
laag
laag
laag
laag
laag
laag
laag
hoog
gemiddeld
gemiddeld
laag
gemiddeld

hoog

gemiddeld

gemiddeld

laag

laag

gemiddeld

laag

$0 \quad$ laag

2

0

0

0

0

0

0

0

0

0

2

1

1

0

1 
$-49-$

Tabel 4.13. Regionale werkloosheidspercentages onder schoolverlaters per RBA-gebied

\begin{tabular}{lll}
\hline opleiding & werkloosheidspercentage & typering \\
\hline
\end{tabular}

16. MBO Verpleging \& Ziekenverzorging

$\begin{array}{llrl}1 & \text { Groningen } & 17 & \text { hoog } \\ 2 & \text { Friesland } & 9 & \text { hoog } \\ 3 & \text { Drenthe } & 12 & \text { hoog } \\ 4 & \text { IJssel-Vecht } & 8 & \text { gemiddeld } \\ 5 & \text { Twente } & 7 & \text { gemiddeld } \\ 6 & \text { Midden-IJssel } & 8 & \text { gemiddeld } \\ 7 & \text { Veluwe } & 4 & \text { laag } \\ 8 & \text { Arnhem/Oost-Gelderland } & 7 & \text { gemiddeld } \\ 9 & \text { Nijmegen/Rivierenland } & 11 & \text { hoog } \\ 10 & \text { Flevoland } & 4 & \text { laag } \\ 11 & \text { Oost-Utrecht } & 4 & \text { laag } \\ 12 & \text { Midden- en West-Utrecht } & 11 & \text { hoog } \\ 13 & \text { Gooi en Vechtstreek } & - & \\ 14 & \text { Noord-Holland Noord } & 4 & \text { laag } \\ 15 & \text { Amsterdam/Zaanstreek/Waterland } & 4 & \text { gemiddeld } \\ 16 & \text { Kennemer-/Amstel- en Meerlanden } & 7 & \text { laag } \\ 17 & \text { Rijnstreek } & 2 & \text { laag } \\ 18 & \text { Den Haag/Delft } & 4 & \text { gemiddeld } \\ 19 & \text { Drechtsteden } & 5 & \text { laag } \\ 20 & \text { Rijnmond } & 5 & \text { laag } \\ 21 & \text { Zeeland } & 2 & \text { laag } \\ 22 & \text { Westelijk Noord-Brabant } & 1 & \text { laag } \\ 23 & \text { Breda en omstreken } & 0 & \text { gemiddeld } \\ 24 & \text { Midden-Brabant } & 2 & \text { hoog } \\ 25 & \text { Noord-Oost Brabant } & 2 & \text { gemiddeld } \\ 26 & \text { Zuid-Oost Brabant } & \text { laag } \\ 27 & \text { Midden- en Noord-Limburg } & 5 & \text { gemiddeld } \\ 28 & \text { Zuid-Limburg } & 5 & \text { hoog }\end{array}$


$-50-$

Tabel 4.14. Regionale werkloosheidspercentages onder schoolverlaters per RBA-gebied

opleiding werkloosheidspercentage typering

\section{MBO Economisch-Administratief}

\begin{tabular}{ll}
1 & Groningen \\
2 & Friesland \\
3 & Drenthe \\
4 & IJssel-Vecht \\
5 & Twente \\
6 & Midden-IJssel \\
7 & Veluwe \\
8 & Arnhem/Oost-Gelderland \\
9 & Nijmegen/Rivierenland \\
10 & Flevoland \\
11 & Oost-Utrecht \\
12 & Midden- en West-Utrecht \\
13 & Gooi en Vechtstreek \\
14 & Noord-Holland Noord \\
15 & Amsterdam/Zaanstreek/Waterland \\
16 & Kennemer-/Amstel- en Meerlanden \\
17 & Rijnstreek \\
18 & Den Haag/Delft \\
19 & Drechtsteden \\
20 & Rijnmond \\
21 & Zeeland \\
22 & Westelijk Noord-Brabant \\
23 & Breda en omstreken \\
24 & Midden-Brabant \\
25 & Noord-Oost Brabant \\
26 & Zuid-Oost Brabant \\
27 & Midden- en Noord-Limburg \\
28 & Zuid-Limburg \\
\hline &
\end{tabular}

hoog
hoog
hoog
gemiddeld
hoog
laag
laag
gemiddeld
hoog
laag
laag
hoog
laag
hoog
gemiddeld
laag
laag
gemiddeld
hoog
laag
laag
gemiddeld
laag
gemiddeld
hoog
hoog
laag
hoog


Tabel 4.15. Regionale werkloosheidspercentages onder schoolverlaters per RBA-gebied opleiding

\section{MBO Bestuurlijk}

\begin{tabular}{|c|c|c|}
\hline Groningen & 7 & gemiddeld \\
\hline Friesland & 41 & hoog \\
\hline Drenthe & 8 & gemiddeld \\
\hline IJssel-Vecht & 6 & gemiddeld \\
\hline Twente & 26 & hoog \\
\hline Midden-IJssel & - & \\
\hline Veluwe & 0 & laag \\
\hline Arnhem/Oost-Gelderland & 11 & gemiddeld \\
\hline Nijmegen/Rivierenland & - & \\
\hline Flevoland & - & \\
\hline Oost-Utrecht & 5 & laag \\
\hline Midden- en West-Utrecht & 21 & hoog \\
\hline Gooi en Vechtstreek & - & \\
\hline Noord-Holland Noord & 9 & gemiddeld \\
\hline Amsterdam/Zaanstreek/Waterland & 6 & gemiddeld \\
\hline Kennemer-/Amstel- en Meerlanden & 8 & gemiddeld \\
\hline Rijnstreek & 5 & laag \\
\hline Den Haag/Delft & 13 & gemiddeld \\
\hline Drechtsteden & 18 & gemiddeld \\
\hline Rijnmond & 3 & laag \\
\hline Zeeland & 0 & laag \\
\hline Westelijk Noord-Brabant & - & \\
\hline Breda en omstreken & - & \\
\hline Midden-Brabant & - & \\
\hline Noord-Oost Brabant & 9 & gemiddeld \\
\hline Zuid-Oost Brabant & 18 & gemiddeld \\
\hline Midden- en Noord-Limburg & 4 & laag \\
\hline Zuid-Limburg & 30 & hoog \\
\hline
\end{tabular}


Tabel 4.16. Regionale werkloosheidspercentages onder schoolverlaters per RBA-gebied opleiding

\section{MBO Sociaal-Cultureel}

\begin{tabular}{ll}
1 & Groningen \\
2 & Friesland \\
3 & Drenthe \\
4 & IJssel-Vecht \\
5 & Twente \\
6 & Midden-IJssel \\
7 & Veluwe \\
8 & Arnhem/Oost-Gelderland \\
9 & Nijmegen/Rivierenland \\
10 & Flevoland \\
11 & Oost-Utrecht \\
12 & Midden- en West-Utrecht \\
13 & Gooi en Vechtstreek \\
14 & Noord-Holland Noord \\
15 & Amsterdam/Zaanstreek/Waterland \\
16 & Kennemer-/Amstel- en Meerlanden \\
17 & Rijnstreek \\
18 & Den Haag/Delft \\
19 & Drechtsteden \\
20 & Rijnmond \\
21 & Zeeland \\
22 & Westelijk Noord-Brabant \\
23 & Breda en omstreken \\
24 & Midden-Brabant \\
25 & Noord-Oost Brabant \\
26 & Zuid-Oost Brabant \\
27 & Midden- en Noord-Limburg \\
28 & Zuid-Limburg \\
& \\
\hline
\end{tabular}

\author{
gemiddeld \\ hoog \\ gemiddeld \\ hoog \\ gemiddeld \\ gemiddeld \\ laag \\ gemiddeld \\ hoog \\ laag \\ gemiddeld \\ laag \\ laag \\ gemiddeld \\ hoog \\ laag \\ gemiddeld \\ gemiddeld \\ laag \\ laag \\ gemiddeld \\ gemiddeld \\ gemiddeld \\ laag \\ gemiddeld \\ gemiddeld \\ hoog
}


$-53-$

Tabel 4.17. Regionale werkloosheidspercentages onder schoolverlaters per RBA-gebied

opleiding

werkloosheidspercentage

typering

\section{0. $M B O$ Verzorging}

1 Groningen

Friesland

Drenthe

14

IJssel-Vecht

Twente

Midden-IJssel

Veluwe

Arnhem/Oost-Gelderland

Nijmegen/Rivierenland

Flevoland

Oost-Utrecht

Midden- en West-Utrecht

Gooi en Vechtstreek

Noord-Holland Noord

15 Amsterdam/Zaanstreek/Waterland

16 Kennemer-/Amstel- en Meerlanden

17 Rijnstreek

18 Den Haag/Delft

19 Drechtsteden

20 Rijnmond

21 Zeeland

22 Westelijk Noord-Brabant

23 Breda en omstreken

24 Midden-Brabant

25 Noord-Oost Brabant

26 Zuid-Oost Brabant

27 Midden- en Noord-Limburg

28 Zuid-Limburg

hoog
hoog
hoog
gemiddeld
hoog
laag
laag
hoog
gemiddeld
laag
laag
gemiddeld
gemiddeld
laag
laag
laag
gemiddeld
laag
laag
laag
gemiddeld
laag
gemiddeld
laag
laag
laag
hoog




\section{BIJLAGE A: LANDELIJKE WERKLOOSHEID VAN DE BEROEPSBEVOLKING}

In deze bijlage zal worden ingegaan op de totstandkoming van de typeringen van de landelijke werkloosheid onder de gehele beroepsbevolking, onderscheiden naar een vijftigtal opleidingstypen. De werkloosheidspercentages met betrekking tot de gehele beroepsbevolking worden berekend op basis van het ISVA-bestand (Informatiesysteem Vraag en Aanbod) van de arbeidsvoorzieningsorganisaties.

Aan dit ISVA-bestand moeten een aantal eisen worden opgelegd om de omvang van het zogenaamde Bemiddelingsbestand Zonder Baan (BZB) te bepalen. Om als werkloos te worden geregistreerd moet, naast het feit dat een arbeidskracht blijk moet geven van de wens om te werken door zich in te schrijven als werkzoekende bij het arbeidsbureau, aan de volgende eisen worden voldaan:

- men moet in staat en bereid zijn een betaalde werkkring te aanvaarden en men mag geen (tijdelijke) betaalde baan hebben;

- men moet onmiddellijk beschikbaar zijn om een betaalde baan te aanvaarden;

- de gezochte baan moet een omvang hebben van tenminste 20 uur per week, dat wil zeggen: men moet op zoek zijn naar een hoofdactiviteit op de arbeidsmarkt;

- men moet jonger zijn dan 65 jaar.

Op basis van dit bestand zijn de werkloosheidspercentages per opleidingstype berekend, door het aantal werkloze personen met een bepaalde opleidingsachtergrond te relateren aan het aantal werkzame personen plus het aantal werklozen met de desbetreffende opleidingsachtergrond. Daarbij is gebruik gemaakt van het aantal werkzame personen per opleidingstype volgens de Enquête Beroepsbevolking (EBB) 1990 van het CBS, omdat de cijfers voor 1991 nog niet beschikbaar waren. Dit laatste zal doorgaans slechts tot een zeer kleine vertekening leiden.

De werkloosheidspercentages voor de beroepsbevolking (WBB) worden vervolgens vertaald naar kwalitatieve typeringen op basis van een vijfpuntsschaal. Daarbij wordt van het volgende uitgegaan: indien de werkloosheid gelijk is aan de frictiewerkloosheid is er sprake van een evenwichtige arbeidsmarkt. Uit analyses van het Centraal Planbureau (CPB) blijkt dat de frictiewerkloosheid in Nederland de afgelopen jaren is gestegen. Afhankelijk van de berekeningswijze bedraagt de frictiewerkloosheid tussen de $3,5 \%$ en $5 \%$ (zie Centraal Economisch Plan 1988). Derhalve zijn de werkloosheidspercentages van de beroepsbevolking gerelateerd aan een frictiewerkloosheid van $5 \%$. Overigens komt deze frictiewerkloosheid momenteel overeen met het gemiddelde van de werkloosheidspercentages over alle opleidingstypen. Vervolgens zijn de overige grenzen bepaald met behulp van de 
standaarddeviatie van de werkloosheidspercentages van de beroepsbevolking over alle opleidingstypen ${ }^{2}$. Dit heeft tot gevolg dat de typeringen van de werkloosheidspercentages voor de beroepsbevolking op basis van onderstaande grenzenindeling zijn toegekend:

Schema 1. Typering van de landelijke werkloosheidspercentages

werkloosheidspercentage typering

$\begin{array}{rlrl}\text { WBB } & \leq 1 \% & & \text { relatief erg laag } \\ 1 \%<\text { WBB } \leq 3 \% & \text { relatief laag } \\ 3 \%<\text { WBB } \leq 7 \% & \text { min of meer in evenwicht } \\ 7 \%<\text { WBB } \leq 10 \% & \text { relatief hoog } \\ 10 \%<\text { WBB } & \text { relatief erg hoog }\end{array}$

Daarnaast is ook de ontwikkelingstrend van de landelijke werkloosheidscijfers bepaald. Deze ontwikkelingstrend is bepaald door voor elk opleidingstype het aantal werklozen in april 1991 te relateren aan het aantal werklozen in april 1990. Vervolgens wordt van het op deze wijze verkregen quotiënt de waarde 1 afgetrokken. Op deze wijze wordt de ontwikkelingstrend genormeerd om de waarde 0 . De ontwikkelingstrend heeft derhalve de waarde 0 als het aantal werklozen in een bepaald opleidingstype in april 1991 gelijk is aan het aantal werklozen voor hetzelfde opleidingstype in 1990. Indien de waarde van de trend kleiner is dan 0, is er sprake van een dalende werkloosheid. Een waarde van de trend groter dan 0 komt overeen met een toenemende werkloosheid.

Hoewel ook het totale aantal werklozen tussen april 1990 en april 1991 is gedaald zou er bij de vaststelling van de ontwikkelingstrend van veel opleidingstypen een vertekening kunnen optreden doordat er in het ISVA bestand van april 1991 bij meer werklozen niet exact is achterhaald welke opleiding men heeft gevolgd (alleen opleidingsniveau is bekend). Geprobeerd is voor deze vertekening te corrigeren door de werklozen in de restgroepen 'opleidingstype onbekend' toe te delen aan de overige opleidingstypen op het overeenkomstige opleidingsniveau. Daartoe is het aandeel van een bepaald opleidingstype in het totaal van de opleidingen op een bepaald niveau vastgesteld. Vervolgens is met behulp van dit aandeel de restgroep aan de overige opleidingstypen op het desbetreffende opleidingsniveau toegerekend.

Ook de ontwikkelingstrend van de werkloosheid (TW) is vertaald in een kwalitatieve typering. Evenals bij de classificatie van de werkloosheidspercentages, is de grenzenindeling bepaald met

2. Wieling, M.H., A. de Grip, E.J.T.A. Willems (1990), Een systematische kwalitatieve typering van arbeidsmarktinformatie, ROA-W-1990/8, Maastricht. 
$-56-$

behulp van het gemiddelde en de standaardafwijking over de berekende quotiënten van de werkloosheid in april 1991 en de werkloosheid in april 1990 voor alle opleidingstypen ${ }^{3}$. Het gemiddelde is hier echter, vanwege de daling van het totaal aantal werklozen ten opzichte van april 1990, kleiner dan $1.0 \mathrm{~m}$ in eerste instantie toch een normering gerelateerd aan de waarde 1 te verkrijgen, zijn de oorspronkelijke, met het gemiddelde en de standaardafwijking, verkregen grenzen gedeeld door het gemiddelde. Daarna wordt van de op deze wijze verkregen grenzen nog de waarde 1 afgetrokken om een normering om de waarde 0 te verkrijgen. Voor de trend van de werkloosheid wordt dan onderstaande grenzenindeling verkregen:

Schema 2. Typering van de ontwikkelingstrend van de landelijke werkloosheid

ontwikkelingstrend werkloosheid

$T W \leq-0.30$

$-0.30<\mathrm{TW} \leq-0.10$

$-0.10<\mathrm{TW} \leq 0.10$

$0.10<\mathrm{TW} \leq 0.30$

$0.30<\mathrm{TW}$ typering

sterk dalend

dalend

constant

stijgend

sterk stijgend

Tenslotte moet worden opgemerkt dat in het geval van een sterk dalende of stijgende trend wordt nagegaan of het werkloosheidspercentage groter of kleiner dan $5 \%$. Indien er sprake is van een werkloosheidspercentage kleiner of gelijk aan $5 \%$, wordt een in eerste instantie als 'sterk stijgende' of 'sterk dalende' getypeerde ontwikkelingstrend omgezet in respectievelijk een 'stijgende' of 'dalende' trendmatige ontwikkeling. Dit laatste is gedaan omdat bij dergelijk lage werkloosheidspercentages relatief geringe verschuivingen reeds snel leiden tot een extreme typering.

3. Zie Wieling, M.H., A. de Grip, E.J.T.A. Willems (1990), Een systematische kwalitatieve typering van arbeidsmarktinformatie, ROA-W-1990/8, Maastricht. 


\section{BIJLAGE B: LANDELIJKE WERKLOOSHEID ONDER SCHOOLVERLATERS}

De landelijke werkloosheidspercentages voor schoolverlaters (WSV) zijn, evenals de werkloosheidspercentages voor de totale beroepsbevolking, berekend op basis van het ISVA-bestand. Om de werkloosheid onder schoolverlaters voor heel Nederland te bepalen, zijn uit het BZBbestand de werklozen geselecteerd die als schoolverlater staan ingeschreven en tevens korter dan één jaar werkzoekend zijn. Dit laatste is gedaan om de schoolverlaters die reeds een aantal jaren geleden uitstroomden buiten beschouwing te laten. Door het aantal werkloze schoolverlaters te relateren aan het totaal aantal schoolverlaters met de desbetreffende opleidingsachtergrond in het voorafgaande schooljaar kan een werkloosheidsindicator voor schoolverlaters van het desbetreffende schooljaar worden geconstrueerd. Daarbij is gebruik gemaakt van de door het ROA gemaakte prognoses van het aantal nieuwkomers op de arbeidsmarkt.

Per opleidingstype wordt het landelijk werkloosheidspercentage vertaald in een kwalitatieve typering van de ernst van de werkloosheid, waarbij de typering wordt gerelateerd aan het gemiddelde werkloosheidspercentage over alle opleidingstypen.

Schema 3. Typering van de landelijke werkloosheidspercentages onder schoolverlaters

\begin{aligned} & \hline werkloosheidspercentage typering \\ &\[ W S V \leq 2 \% \] relatief erg laag \\ & $2 \%<W S \leq 4 \%$ relatief laag \\ & $4 \%<W S \leq 10 \%$ gemiddeld \\ & $10 \%<W S \leq 30 \%$ relatief hoog \\ & $30 \%<W S V$ relatief erg hoog \\ & \hline\end{aligned}

De grenzen kunnen in dit geval niet worden bepaald op basis van het gemiddelde en de standaarddeviatie van de werkloosheidspercentages onder schoolverlaters, omdat de standaardafwijking relatief groot is ten opzichte van het gemiddelde. Derhalve wordt in plaats van de symmetrische methode, de zogenaamde kwantielenmethode toegepast om de grenzen te bepalen $^{4}$. Door deze methode wordt respectievelijk 10\%, 20\%, 40\%, 20\% en $10 \%$ van de berekende waarden van de werkloosheidspercentages getypeerd als relatief 'erg hoog', 'hoog', 'gemiddeld', 'laag' en 'erg laag'. Deze methode levert de bovenstaande grenzenindeling op.

4. Zie Wieling, M.H., A. de Grip, E.J.T.A. Willems (1990), Een systematische kwalitatieve typering van arbeidsmarktinformatie, ROA-W-1990/8, Maastricht. 


\section{BIJLAGE C: REGIONALE WERKLOOSHEID ONDER SCHOOLVERLATERS}

Om de regionale werkloosheid onder schoolverlaters (WSVR) te bepalen, is het aantal werkloze schoolverlaters voor elk opleidingstype naar de 28 RBA-gebieden opgesplitst. Door deze aantallen te relateren aan uitstroomgegevens kan voor de opleidingsrichtingen een werkloosheidspercentage voor elk RBA-gebied worden verkregen. Daarbij is voor de uitstroomgegevens gebruik gemaakt van de Regionalisering Uitstroom Voortgezet Onderwijs (RUVO) prognoses 5 . De in RUVO onderscheiden opleidingstypen zijn in ROA-opleidingstypen omgezet, hetgeen heeft geresulteerd in regionale uitstroomgegevens voor 17 opleidingstypen.

Daarbij moet worden opgemerkt dat de werkloze schoolverlaters zijn gemeten in april 1991 . Over het algemeen zijn dit schoolverlaters van het jaar 1989/1990. Van dit schooljaar zijn echter geen RUVO-prognoses gepubliceerd. Derhalve is gebruik gemaakt van de RUVOgegevens met betrekking tot het schooljaar 1990/1991.

Net als aan de landelijke werkloosheidspercentages worden aan de regionale werkloosheidspercentages kwalitatieve typeringen toegekend. Daarmee worden per opleidingstype de werkloosheidspercentages van de verschillende RBA-gebieden vergeleken met het landelijke werkloosheidspercentage van het desbetreffende opleidingstype. Daartoe is per opleidingstype een grenzenindeling gemaakt op basis van het landelijke werkloosheidscijfer en de standaardafwijking van de regionale werkloosheidspercentages voor het desbetreffende opleidingstype. Dit houdt in dat voor de 17 opleidingstypen waarvoor een regionaal werkloosheidspercentage is berekend, verschillende grenzenindelingen zijn bepaald.

Overigens moet worden opgemerkt dat de typering van de regionale werkloosheidspercentages onder schoolverlaters plaatsvindt op basis van een driepuntsschaal. Dit verkleint de kans dat (kleine) vertekeningen in de gebruikte RUVO-prognoses tot een verkeerde typering leiden. De grenzenindelingen voor de afzonderlijke opleidingstypen staan in het onderstaande schema weergegeven.

5. Vermeulen, M. (1990), Regionalisering uitstroom voortgezet onderwijs (RUVO), OAVrapport 90-22, INRO-TNO 90/NS/041, Delft. 
Schema 4. Typering van de regionale werkloosheidspercentages onder schoolverlaters

werkloosheidspercentage

2. MAVO en onderbouw HAVONWO

3. LBO Agrarisch

4. LBO Technisch

5. LBO Haven \& Vervoer

6. $L B O$ Economisch-Administratief

\section{7. $L B O$ Verzorgend}

10. Bovenbouw HAVONWO

11. MBO Agrarisch

12. MBO Technisch Laboratorium

13. MBO Technisch

14. MBO Haven \& Vervoer

15. MBO Medisch Laboratorium

$\begin{aligned} \text { WSVR } \leq 17 \% & \text { laag } \\ 17 \%<\text { WSVR } \leq 26 \% & \text { gemiddeld } \\ 26 \%<\text { WSVR } & \text { hoog } \\ \text { WSVR } \leq 8 \% & \text { laag } \\ 8 \%<\text { WSVR } \leq 18 \% & \text { gemiddeld } \\ 18 \%<\text { WSVR } & \text { hoog }\end{aligned}$

$\begin{aligned} \text { WSVR } \leq 5 \% & \text { laag } \\ 5 \%<\text { WSVR } \leq 10 \% & \text { gemiddeld } \\ 10 \%<\text { WSVR } & \text { hoog }\end{aligned}$

WSVR $\leq 2 \% \quad$ laag

$2 \%<W S V R \leq 6 \% \quad$ gemiddeld $6 \%<$ WSVR hoog

$\begin{aligned} \text { WSVR } \leq 24 \% & \text { laag } \\ 24 \%<\text { WSVR } \leq 41 \% & \text { gemiddeld } \\ 41 \%<\text { WSVR } & \text { hoog }\end{aligned}$

WSVR $\leq 15 \% \quad$ laag $15 \%<$ WSVR $\leq 24 \% \quad$ gemiddeld $24 \%<$ WSVR hoog

WSVR $\leq 17 \% \quad$ laag $17 \%<$ WSVR $\leq 39 \% \quad$ gemiddeld $39 \%<$ WSVR hoog

$\begin{aligned} \text { WSVR } \leq 3 \% & \text { laag } \\ 3 \%<\text { WSVR } \leq 6 \% & \text { gemiddeld } \\ 6 \%<\text { WSVR } & \text { hoog }\end{aligned}$

$\begin{array}{rlr}\text { WSVR } \leq 15 \% & \text { laag } \\ 15 \%<\text { WSVR } \leq 45 \% & \text { gemiddeld }\end{array}$
$45 \%<$ WSVR hoog

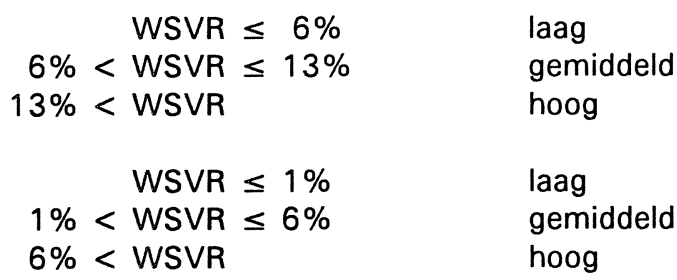

$\begin{aligned} \text { WSVR } \leq 0,5 \% & \text { laag } \\ 0,5 \%<\text { WSVR } \leq 1,5 \% & \text { gemiddeld } \\ 1,5 \%<\text { WSVR } & \text { hoog }\end{aligned}$


$-60-$

Schema 4 (vervolg). Typering van de regionale werkloosheidspercentages onder schoolverlaters

werkloosheidspercentage

typering

16. $M B O$ Verpleging \& Ziekenverzorging

WSVR $\leq 4 \%$

$4 \%<$ WSVR $\leq 8 \%$

$8 \%<$ WSVR

laag

gemiddeld

hoog

17. $M B O$ Economisch \& Administratief

WSVR $\leq 7 \%$

laag

$7 \%<$ WSVR $\leq 11 \%$

$11 \%<$ WSVR

gemiddeld

hoog

18. MBO Bestuurlijk

WSVR $\leq 5 \%$

laag

$5 \%<$ WSVR $\leq 18 \%$

$18 \%<$ WSVR

gemiddeld

hoog

19. MBO Sociaal-Cultureel

WSVR $\leq 5 \%$

laag

$5 \%<$ WSVR $\leq 14 \%$

gemiddeld

$14 \%<$ WSVR

hoog

20. $M B O$ Verzorging

$$
\text { WSVR } \leq 7 \%
$$

$7 \%<$ WSVR $\leq 13 \%$

laag

$13 \%<$ WSVR

gemiddeld

hoog 